\title{
Local traditions v. academic law: collateral rights on movables in Holland (c. 1300-c. 1700)
}

\author{
Dave De ruysscher \\ Associate Professor at Tilburg University and Associate Professor at Vrije \\ Universiteit Brussels; Warandelaan 2, 5037 AB Tilburg, Nederland \\ dderuyss@vub.ac.be \\ Ilya Kotlyar \\ Postdoctoral Researcher at Tilburg University, Warandelaan 2, 5037 AB Tilburg, \\ Nederland
}

\section{Summary}

In the County of Holland, in the sixteenth and seventeenth centuries the rules regarding security interests in movables changed fundamentally. Rules of doctrine came to be combined with rules found in local law, that is the bylaws of cities and regions. This went together with the re-interpreting of fragments of older bylaws. In $163_{1}$ Grotius' Inleidinghe categorized the lien of the unpaid seller after delivery of the merchandise sold as entailing a reivindicatio. This new rule was adopted in cities in Holland, even though it ran counter the earlier approach that third-party effects of sales in this regard were very limited. Also, the new line of thought that holders with a legitimate title did not respond to pledgees pushed out older conceptions on tracing for some special pledges. In their legal writings Dutch authors after Grotius attempted to construe consistent solutions; in the legislative practice of cities, older rules could be preferred over new ones. Bylaws of cities, to which authors of Roman-Dutch doctrine referred as well, stipulated limits on tracing by unpaid sellers. All the mentioned developments were not determined by changes in the market, even though they could be incited by them. Legal change in Holland, even in the Golden Age of the seventeenth century, was due more to the embracing of academic ideas than to responsiveness to economic conditions.

\section{Keywords}

debt enforcement - reception - security interests - pledge - seller's lien - insolvency 
This article ${ }^{1}$ focuses on the creative phases of Roman-Dutch doctrine and the local ordinances of Holland with regard to non-possessory security interests in movables. Between approximately 1300 and 1700, in the province of Holland, at several levels of government (city, bailiwick) and in different sources of law (municipal and regional bylaws, princely ordinances, procedural regulations of courts, doctrine), rules ensuring the protection of secured creditors changed profoundly. These transitions were more fundamental for non-possessory securities on movables than with regard to hypothecs on land and immovable property $^{2}, 3$. In particular the legal positions of unpaid sellers and of creditors entitled in non-possessory pledges were fundamentally adjusted. Hereafter, it will be argued that these changes were not very much determined by shifting economic conditions, even though they were responses to developments in the market as well; instead, the adaptations of law mostly interacted with changing conceptions of lawyers.

The views of the latter were evolving as the result of three interacting factors. The first one was the reception of Roman law, from within contemporary academic doctrine, which supplemented but also changed local legal traditions. Secondly, the osmosis between both local and academic law that came after, involved the constant re-interpretation of - often ambiguous - sources from new viewpoints and on the basis of ideas stemming from both traditions; this process incited the creation of new rules. Thirdly, at times, commercial

1 This article was written as part of the ERC-funded project CLLS (ERC Starting Grant 714759). Comments are welcome at d.deruysscher@uvt.nl.

2 For recent appraisals of the late-medieval and early modern Holland law on hypothecs of immovable property and annuities by economic historians, emphasizing continuity, see B. van Bavel, J. Dijkman, E. Kuijpers and J. Zuijderduijn, The organisation of markets as a key factor in the rise of Holland from the fourteenth to the sixteenth century, A test case for an institutional approach, Continuity and Change, 27 (2012), p. 347-378; Ch. van Bochove, H. Deneweth and J. Zuijderduijn, Real estate and mortgage finance in England and the Low Countries, 1300180o, Continuity and Change, 30 (2015), p. 9-38; C.J. Zuijderduijn, Medieval capital markets, Markets for renten, state formation and private investment in Holland (1300-1550), Leiden 2009.

3 Throughout this article 'pledge' refers to a security interest that is established with a contract. 'Pledge' also encompasses non-possessory pledges, i.e. when the security provider (pledgor) retains possession of the pledged assets. General pledges do not detail the assets under pledge but instead provide that they are for 'all assets' of the debtor. 'Hypothec' refers to a non-possessory pledge. 'Tacit hypothec' is a security interest established by law. 'Seizure', 'attachment' and 'sequestration' are used as synonyms, applying to the locking of assets that is either based on a court order or not. 'Executory proceedings' regard the sale of pledged goods by the pledgee. 'Collateral rights' and 'security interests' are used interchangeably. 'Lien' and 'encumbrance', also used interchangeably, refer to a security interest that is not rooted in a contract and that is not an absolute title. 
practice invited for reform, not only of doctrine but also of the local, that is municipal and regional law. But, however, as was mentioned, even though practices of merchants and provisions in contracts could serve as inspiration for new bylaws, legislation or doctrinal rules they did not impose legal change or provide solutions that could easily be transposed into law 4 .

The thesis of this article is that the abovementioned developments brought about uncertainty and - temporary - divergences between academic and local law, the latter in particular being the municipal law of cities. In the second half of the sixteenth century and in the early seventeenth century differences of opinion existed between scholars, judges of higher courts and aldermen of cities and bailiwicks. Yet over the course of the 1600 s these differences were solved for a large degree. With regard to movable securities, legal authors crafted easily manageable rules of thumb. The maxim 'les meubles n'ont pas de suite' ('mobilia non habent sequelam') was their guiding line, and it almost became an effective rule of positive law, with few exceptions. Yet, also, opposition from within powerful cities, and in particular Amsterdam, meant that local rules were polished in answer to the developing views that were found within Roman-Dutch legal scholarship. Amsterdam limited the broad rights of tracing (droit de suite) for unpaid sellers, which were devised in doctrine. Moreover, irrespective of new laws for Holland, the Amsterdam legislators maintained a tradition of putting special and general pledges on the same level.

A first paragraph provides an overview of how legal developments in late medieval and early modern Holland regarding movable collateral are described in present-day legal-historical and economic-historical literature. The second and third parts address the interactive legal features of movable securities in late medieval and sixteenth-century Holland and their stages of development. In a fourth paragraph, it will be made evident that Grotius' approaches in the early decades of the 1600 s enhanced the divide that was growing between local rules and academic doctrine. A fifth section details how the legal scholars Van Leeuwen and Groenewegen aimed at establishing a doctrinal framework that was more consistent.

4 See for this argument also D. De ruysscher, From usages of merchants to default rules: Practices of trade, ius commune and urban law in early modern Antwerp, The Journal of Legal History, 33/1 (2012), p. 3-29. A contrary opinion is offered in O. Gelderblom, Cities of commerce, The institutional foundations of international trade in the Low Countries, 1250-1650, Princeton 2013. For a critique on this latter view, see D. De ruysscher and J. Puttevils, The art of compromise, Legislative deliberation on marine insurance institutions in Antwerp (c. 1550-c. 1570), BMGN-Low Countries Historical Review, 130/3 (2015), p. 25-49. 


\section{Collateral rights on movables in late medieval and early modern Holland: a state of the art}

Collateral rights, or security interests, can be defined as the rights which creditors receive in the goods of their debtor and which can be materialized, in one way or another, in the event of the debtor's default. When defined as such, collateral rights comprise possessory and non-possessory pledges, as well as the right of the unpaid seller on the assets that were delivered but which remain unpaid (hereinafter: the unpaid seller's lien). Moreover, conventional pledges, as well as tacit hypothecs that are established by law, fall within this broad category 5 .

In North-West Europe, at the end of the Middle Ages and the beginning of the early modern period, the legal regimes of collateral rights with regard to movables were shifting. Much more research is needed in this regard, even though as concerning the lien of the unpaid seller and non-possessory pledges, literature on the rules applying in the Low Countries, and in Holland in particular, is extensive. However, the focus of this research has mostly been on substantive law, as found in princely legislation, local bylaws and in legal scholarship, and it did not analyze judicial practice or rules of procedure ${ }^{6}$. Combin-

5 Lawyers still grapple with a precise definition of security interests, see M. Bridge, The scope and limits of security interests, in: H. Eidenmüller and E.-M. Kieninger (eds), The future of secured credit in Europe, Berlin 2008, p. 180-214, and E.-M. Kiesinger, Commentary, in the same volume, p. 215-222. On the necessity to study insolvency, pledge and other collateral rights in a combined fashion, see J. Armour, A. Menezes, M. Uttamchandani, and K. van Zwieten, How do creditor rights matter for debt finance?, A review of empirical evidence, in: F. Dahan (ed.), Research Handbook on Secured Financing in Commercial Transactions, Cheltenham 2015, p. $3^{-25}$, at p. 25 .

6 On the seller's lien, in doctrine and local bylaws: R. Feenstra, Reclame en revindicatie, Onderzoekingen omtrent de rol in de ontwikkelingsgeschiedenis van het recht van reclame gespeeld door den Romeinsrechtelijken regel omtrent eigendomsovergang en prijsbetaling bij koop (Inst. 2.1.41), Haarlem 1949, and many later publications: R. Feenstra, De pecuniaire bescherming van de koper te goeder trouw van andermans zaak in Hugo de Groots De Iure Belli ac Pacis, in:J. Van der Westhuizen, et al. (eds), Huldigingsbundel Paul van Warmelo, Pretoria 1984, p. 70-80; R. Feenstra, De Romeinsrechtelijke prijsbetalingsregel en het recht van reclame van artikel 7:39-44 BW, Ars Aequi, 55 (2006), p. 876-883; R. Feenstra, Eigendomsoverdracht bij koop en terugvorderingsrecht van de onbetaalde verkoper, Romeins recht en Middeleeuws handelsrecht, Tydskrif vir Hedendaags Romeins-Hollandse Reg, 50 (1987), p. 127-138; R. Feenstra, Revendication de meubles et 'Lösungsrecht' de tiers acquéreurs (droitromain, droit wisigothique, droit coutumier médiéval en Espagne et dans le Midi de la France), in: R. Feenstra, et al. (eds), Collatio iuris romani, Études dédiées à Hans Ankum à l'occasion de son 65e anniversaire, Amsterdam 1995, p. 87-104 [also in: R. Feenstra, Histoire du droit savant (13e-18e siècle), 
ing these sources into an analysis that addresses developments as found in doctrine, bylaws and court practices, as well as in contracts, allows for a more thorough assessment of the chronology of innovations in legal thinking and legal practice.

Moreover, such a broad approach is necessary in order to bridge gaps between legal-historical and economic-historical literature on the mentioned themes. The legal-historical analysis of doctrine and legislation has yielded the conclusion that movables could be burdened with the claim of an unpaid seller and that this was a general rule in the seventeenth century, with strong antecedents in the later Middle Ages and the sixteenth century ${ }^{7}$. By contrast, as concerning non-possessory pledges of movables, tracing against third parties was excluded if the latter had received the assets on a legitimate basis, in particular if the holders had paid for them. Yet again, this has been considered a rule that applied both in the sixteenth and the seventeenth centuries ${ }^{8}$. The Roman-Dutch doctrine of the seventeenth century on the theme of collateralization of movables has mainly been understood as being a sophistication of local law. The latter was explained and made 'elegant' in Roman-Dutch legal writings.

The red thread in these conclusions is that of continuity. But however, these views can hardly be matched with economic-historical research. Economic historians have with regard to Holland emphasized the novelty of developments, not only in the Golden Age of the seventeenth century, but also for the later Middle Ages. For the 140os, for example, they point at newly emerging

Doctrine et vulgarization par incunables, Aldershot 2005, p. 87-104]; R. Feenstra, Zum Ursprung des Lösungsrechtes beim Kauf gestohlener Sachen auf dem Markte, besonders nach einigen Spanischen und südfranzösischen Quellen, in: K.S. Bader(ed.), Festschrift Guido Kisch, Stuttgart 1955, p. 237-259 [also in: R. Feenstra, Fata iuris romani, Études d'histoire du droit, Leiden 1974, p. 73-95]. Also: D.L. Carey Miller, Transfer of Ownership, in: R. Feenstra and R. Zimmermann (eds), Das römisch-holländische Recht, Fortschritte des Zivilrechts im 17. und 18. Jahrhundert, Berlin 1992, p. 521-540, at p. 531-534. On pledges in Roman-Dutch doctrine and in legislation: E. Koops, Vormen van subsidiariteit, Een historisch-comparatistische studie naar het subsidiariteitsbeginsel bij pand, hypotheek en borgtocht, Den Haag 2013, p. 121-151; A.G. Pos, Hypotheek op roerend goed (bezitloos pandrecht), Enkele rechtshistorische en rechtsvergelijkende beschouwingen, Dordrecht 1970, p. 128-185; v.J.M. van Hoof, Generale zekerheidsrechten in rechtshistorisch perspectief, Dordrecht 2015, p. 85-140; W.J. Zwalve, A labyrinth of creditors, A short introduction to the history of security interests in goods, in: E.-M. Kieninger (ed.), Security rights in movable property in European private law, Cambridge 2004, p. 38-53; W.J. Zwalve, System des Vermögensrechts, in: R. Feenstra and R. Zimmermann (eds), Das römisch-holländische recht, Fortschritte des Zivilrechts im 17. und 18. Jahrhundert, Berlin 1992, p. 105-122.

7 Feenstra, Reclame en reivindicatie (supra, n. 6), p. 159-203.

8 Pos, Hypotheek op roerend goed (supra, n. 6), p. 145. 
secondary markets for annuities and a generalization of clauses of collateral in documents regarding public debt ${ }^{9}$. The seventeenth century was marked by extensive securitization in the Amsterdam market, where shares, futures and options were pledged easily ${ }^{10}$. Unsurprisingly, in both disciplines of legal and economic history the paradigm remains that their object of study is the most relevant. Legal historians generally consider legal authors and academically trained judges as drivers of legal development; economic historians typically put the agency in this regard with merchants and entrepreneurs ${ }^{11}$. However, when considering the realities of sixteenth- and seventeenth-century Holland, either position is too extreme. The changing municipal rules on sales and pledges could not have existed without some backing by legal practitioners and legislators; jurists were not unaware of what was happening in finance and trade. (c.1300-c. 156o)

In the fourteenth century, academic (Roman) law had some influence on the rules that were in use in local constituencies in Holland. These included bailiwicks as well as towns and municipalities ${ }^{12}$. In the sixteenth-century county of Holland, the bailiwicks of Rijnland and Delfland were the most important. Rijnland encompassed the area in which Amsterdam, Leiden and Haarlem were located. Delfland was the region surrounding Delft and Schiedam. These bailiwicks were presided over by bailiffs and aldermen. They implemented princely legislation but also applied the landrecht of their bailiwick and could

9 J. Tracy, A financial revolution in the Habsburg Netherlands, Renten and renteniers in the County of Holland 1515-1565, Berkeley 1985. This author claims that in Holland state bonds in the form of annuities were a crucial instrument of state formation and public finance since 1515. New research has shown that in the 1400s in cities in Holland contracts of annuities were handed out to bearer and that they changed hands regularly. See Zuijderduijn, Medieval capital markets (supra, n. 2), p. 231 and p. 242-246. Gelderblom, Cities of Commerce (supra, n. 4), p. 67-69; L. Petram, The world's first stock exchange, New York 2013, p. 175-183.

E.g. E. Stringham, The extralegal development of securities trading in seventeenth-century Amsterdam, The Quarterly Review of Economics and Finance, 43 (2003), p. 321-344. ontwikkeling der rechterlijke organisatie in de Noordelijke Nederlanden tot de Bataafse omwenteling, Deventer 2000, p. 180, 216-224. 
issue bylaws $(\text { keuren })^{13}$. In the course of the sixteenth century, some bailiwicks including those of Rijnland and Delfland, put their law into writing in compilations (costuymen) that were sent in for princely approval (homologatie) ${ }^{14}$. Cities had their own jurisdiction. Their aldermen, who were both administrators and judges in the city's courts, could promulgate bylaws as well. Since the middle of the thirteenth century, they commonly offered the service of registering and ratifying debts. Parties to an agreement could have the agreement enacted in ledgers kept at the town hall and they received certificates containing an excerpt of the agreement in return ${ }^{15}$. The local law that was in force in Holland, as opposed to doctrine, thus encompassed the municipal law of cities and municipalities as well as the regional law as found in keuren and the landrecht that applied at the level of bailiwicks.

In the 1300s, throughout Holland, the rule that delivery conveyed ownership was the most common ${ }^{16}$. Yet also, in case the buyer did not pay the price before or at the moment of delivery, it was possible for the seller to enforce his debt on the movables that he had conveyed to the buyer. This rule came to be applied in Holland local law in the later Middle Ages (see below). In many respects, as will be detailed further, in Holland of the later Middle Ages, sales that had remained unpaid were comparable to non-possessory pledges of movables. A non-possessory pledge provided the creditor (the pledgee) with a security, but the assets charged were left with the debtor. This was most logical in commercial debt: the debtor needed the assets pledged to carry out his business or trade.

In the fourteenth century, the form of the agreement was highly relevant in regard of the enforcement of pledges and debts, among them those out of sale. If the sale had been passed before the aldermen of the constituency, then the seller could apply for a corroborating judgment from those aldermen and have the assets seized from the buyer. Thereupon, the assets were sold publicly. Proof of the local government's ratification of the debt or pledge and of the expiry of the debt was deemed necessary to start executory proceedings, which were called 'panding'. Ratified debts were debts that had been acknowledged

13 G.F. van der Ree-Scholtens, Inventaris van het archief van de Baljuw en Hoge Vierschaar van Rijnland (1539), 1574-1811, Den Haag 1987, p. 7-14.

14 J. Gilissen, Les phases de la codification et de l'homologation des coutumes dans les XVII provinces des Pays-Bas, Tijdschrift voor Rechtsgeschiedenis, 18 (1950), p. 264-265.

15 Van Bochove, Deneweth and Zuijderduijn, Real estate and mortgage finance (supra, n. 2), p., 13 and p. 21.

16 A.S. de Blécourt and H.F.W.D. Fischer, Kort begrip van het oud-vaderlands burgerlijk recht, Groningen 1967 (7th ed.), p. 151-154 (nos 95-97); S.J. Fockema Andreae, Het Oud-Nederlandsch Burgerlijk Recht, Haarlem 1906, I, p. 396. 
by the aldermen in a judgment, or in a certificate if they had been offered for registration at their town hall. These certificates included simply debt certificates, which were registered acknowledgments of debt or contracts, as well as voluntary condemnations which had the value of a judicial sentence. Moreover, the rules regarding evidence, procedure and substantive law were largely intertwined. In many regions of the Low Countries of the 1200 s and 1300s, as was the case in Holland, a debtor was considered liable with his assets only for ratified debts and pledges and for some special - even non-ratified - debts that were defined in local bylaws, such as debts out of lease or salaries ${ }^{17}$.

These rules had come after an earlier stage in which debt enforcement on assets had mostly been an ex post and extrajudicial affair ${ }^{18}$. In the fourteenth and fifteenth centuries, in some cities in Holland this approach persisted for non-ratified debts (it was called 'thoonpand') ${ }^{19}$. The debtor received a notice from the creditor and was invited to choose ('aenwysen') an asset that was handed over or locked until the payment of his debt ${ }^{20}$. It was not required that this action had backing in the original agreement between the creditor and the debtor. No court proceedings were started, or subsequent authorization from the city's aldermen was solicited, except in case executory sale of the seques-

17 On this principle, see De Blécourt and Fischer, Kort begrip (supra, n. 16), p. 263 (no 184); Fockema Andreae, Het Oud-Nederlandsch Burgerlijk Recht (supra, n. 16), II, p. 103-104. See for some examples of municipal bylaws from a later period stating that only ratified debts and special unratified debts of lease can be enforced through panding proceedings: P.J. Blok, Leidsche rechtsbronnen uit de middeleeuwen, Den Haag 1884, p. 103 (no 20) (fifteenth century, ratified debts and debts of lease), and p. 295 (fifteenth century, no panding for non-registered debts); J.C. Breen, Rechtsbronnen der stad Amsterdam, Den Haag 1902, p. 12 (ch. 14, s. 2) (Keur 1415) (listing the debts for which panding can be started); K. Heeringa, Rechtsbronnen der stad Schiedam, Den Haag 1904, p. 96-98 (Keurboek Schiedam (1556), ch. 7) (not restricting panding to ratified debts, but still juxtaposing special debts such as lease); J. Soutendam, Keuren en ordonnantiën der stad Delft van den aanvang der XVIe eeuw tot het jaar 1536, Delft 1870, p. 15-16 (s. 6, 7 and 8), and p. 26 (s. 28) (listing five debts for which panding is allowed without an aldermen's judgment or certificate).

18 H. Planitz, Die Vermögensvollstreckung im deutschen mittelalterlichen Recht, Erster Band: Die Pfändung, Leipzig 1912, p. 1-20.

19 For example, Schiedam: Heeringa, Rechtsbronnen der stad Schiedam (supra, n. 17), p. 48 (June 1497). In other cities, such as Haarlem and Dordrecht, panding was early on considered the only seizure and executory proceedings. See C.L. Hoogewerf, Het Haarlemse stadsrecht (1245), Inleidende beschouwingen, tekst, vertaling en artikelsgewijs commentaar, Amsterdam 2001, appendix 1, p. 13-14 (s. 33) (dating 23 November 1245).

20 In the sixteenth century, the expression 'the debtor who does not offer an asset' ('die geen goed (aen)wyst'), which then referred to a debtor not having assets, was a remnant of this rule. See for example Soutendam, Keuren en ordonnantiën (supra, n. 17), p. 38 (s. 2), and p. 43 (s. 12). 
trated asset was sought or if the debtor contested the creditor's action. Thoonpand served to avoid the slower proceeding of panding. Panding was organized only at certain moments during the year ${ }^{21}$. Imprisonment, as well, could be a feasible alternative to the lengthy panding. In the fourteenth century, at least in some places in Holland it was possible to have a defaulting debtor incarcerated in order to pressure him and his network, even if no panding or other executory proceedings had been started ${ }^{22}$. Sometimes, panding was possible on the assets of strangers, also when there were no certificates or judgments of the debts and even when the latter were not specified in local bylaws ${ }^{23}$. But this was an exception. Even in the event of insolvency, when the debtor ran off and left his estate in disarray, the mentioned distinction between ratified and special debts on the one hand and non-ratified debts on the other was often maintained ${ }^{24}$.

From the middle of the fifteenth century onwards, the procedures of panding and thoonpand fundamentally changed. A first development concerned an extension of the scope of the panding proceeding, which resulted in the merging of panding and thoonpand. Second was a new distinction between accelerated and regular proceedings of panding.

First, panding became possible for all debts, irrespective of their form and contents. In the middle of the 1400's, municipal aldermen still often considered debts in notarial deeds and private contracts as being unofficial because they had not been ratified ${ }^{25}$. In those towns where thoonpand remained in use, it became an enforcement proceeding devised for debts in private, non-ratified

21 Blok, Leidsche rechtsbronnen (supra, n. 17), p. 323-324 (dating from the later fifteenth century); H.G. Hamaker, De middeneeuwsche keurboeken van de stad Leiden, Leiden 1873, p. 24-25 (dating from 1406); J. Huizinga, Rechtsbronnen der stad Haarlem, Den Haag 1911, p. 153-154 (23 May 1463).

Hamaker, De middeneeuwsche keurboeken (supra, n. 21), p. 26-27 (dating from 1406). Cessio bonorum was most probably not known in Holland before the sixteenth century. On cessio bonorum in Holland, see J. Whitman, The moral menace of Roman law and the making of commerce, Some Dutch evidence, The Yale Law Journal, 105 (1995-1996), p. 1841-1889, at p. 1871-1883.

23 Blok, Leidsche rechtsbronnen (supra, n. 17), p. 167 (fifteenth century).

24 Blok, Leidsche rechtsbronnen (supra, n. 17), p. 273 (c. 1450) (seizure of all assets of an absconding debtor, but only for creditors with debt certificates).

25 E.g. Blok, Leidsche rechtsbronnen (supra, n. 17), p. 126 (c. 1440, notarial deeds). However, in 1421 in Leiden it had been decided that obligatiën (private, non-ratified acknowledgments of debts) of English merchants were to be considered as having the same value as ratified debts. See Hamaker, De middeneeuwsche keurboeken (supra, n. 21), p. 202-203 (s. 37). This was made into a general rule only in 1508 , when it became possible to use all kinds of 'letters' and witness reports as proof before the Leiden aldermen's court. See Hamaker, De middeneeuwsche keurboeken (supra, n. 21), p. 326 (book 5, part 1, s. 19). 
documents, whereas the regular panding was to be applied for ratified debts. But incrementally non-ratified debts were considered as sufficient to start a proceeding of panding. For example, it is clear from an Amsterdam turbe of 1562 that any certificate of aldermen, referring to an expired debt, was given priority over informal and notarial debts. Yet also, at the same time, this turbe shows that creditors with notarial deeds and private agreements could be involved in proceedings of panding, even though creditors having aldermen's certificates were given priority ${ }^{26}$. Over the course of the sixteenth century, the notarial deed gained popularity as debt instrument. For example, when in 1565 the city of Amsterdam imposed a numerus clausus on notaries, they appointed only five official notaries ${ }^{27}$. The same system of five city notaries was applied in Leiden since $1577^{28}$. But in 1591 there were already twenty licensed Amsterdam notaries ${ }^{29}$.

The result of the opening up of panding was that defaults on any debt could result in seizure proceedings, which could lead up to the executory sale of the assets seized. Panding changed from executory proceedings into a seizure proceeding. No absolute title of ownership, or a ratified debt, was required for the creditor to lock the debtor's assets in case of his default. In 1656, in an Amsterdam bylaw on procedure it was stated that seizure could be laid on the basis of 'public or liquid' instruments, the latter including obligaties (i.e. acknowledgments of debt to bearer) and bills of exchange (wisselbrieven $)^{30}$. Moreover, the widening of the scope of the panding proceeding meant that thoonpand became incorporated within panding, or when it was maintained, that both proceedings became largely similar ${ }^{31}$. Next to economic circumstances, state

26 Hand-vesten, Privilegien, Handelingen, Costuymen ende Willekeuren der Stadt Aemstelredam ..., s.l. 1624 (hereinafter Willekeuren Amsterdam 1624), I, p. 100 (20 July 1562). A rule comparable to the 1562 Amsterdam rule can be found in the Kenningboek of Leiden, dating 1545 (see note 67) (ch. 4, s. 40). See also van Hoof, Generale zekerheidsrechten (supra, n. 5), p. 131, footnote 223 .

Handt-vesten ende Privilegie van Amstelredam, Mitsgaders sekere Costuymen, Oude-ghebruycken ende Willekeuren der zelver Stede ..., s.l. 1597 (hereafter Willekeuren Amsterdam 1597), p. 145-146 (9 August 1565).

28 Hamaker, De middeneeuwsche keurboeken (supra, n. 21), p. 444-445 (22 November 1577).

$29 \quad$ Willekeuren Amsterdam 1597 (supra, n. 27), p. 146.

30 Ordonnantie ende manieren van procederen voor den gerechte der stadt Amsterdam, Amsterdam 1656, p. 42-43 (s. 4). This was repeated in a 1663 turbe, as well as in a new bylaw of 1779: H. Noordkerk, Handvesten; ofte Privilegien ende octroyen: mitsgaders willekeuren, costuimen, ordonnantien en handelingen der stad Amstelredam ..., Amsterdam 1748, II, p. 501; Ordonnantie op de maniere van procedeeren voor den gerechte der stad Amsterdam, gedresseerd in den jare 1779, Amsterdam 1779, p. 52-53 (s. 4).

$31 \quad$ Planitz, Die Vermögensvollstreckung (supra, n. 18), p. 262 (preliminary judicial authorization for thoonpand), and p. 267-268 (on thoonpand as introductory executory proceed- 
formation mechanisms were at play; restricting thoonpand was purported to limit opportunities for violence among creditors and debtors.

The abovementioned developments influenced other proceedings and contractual practice as well. For example, imprisonment became a subsidiary remedy when there were no assets that could be sequestrated ${ }^{32}$. Moreover, the virtual disappearance of thoonpand enhanced the understanding of pledge as a strictly contractual arrangement. If no agreement had been made on collateral, only a verdict of the town's aldermen could authorize the seizure and public sale of assets. No absolute title of ownership or court order was required to start panding proceedings, only written evidence of the debt, indicating the amount and due date.

At first, it can be assumed, the claimant at a seizure proceeding also had to evidence an agreement on, or a clause of, collateral. There are indeed indications that throughout the later Middle Ages in Holland provisions of pledge became more commonly stipulated in contracts. Clauses of general collateral, 'on all assets present and future', were frequently used in the first decades of the fifteenth century, in ratified annuity contracts ${ }^{33}$ and in ratified acknowledgments of debt ${ }^{34}$. It is an open question as to whether a mounting popularity of provisions of collateral caused the lowering of requirements in panding proceedings, or whether it was the other way round. In any case, the chronology of existing traces from contractual practice and of local bylaws are supportive of the first conclusion.

ings). In Leiden, thoonpand was known in the early fifteenth century, but disappeared afterwards. See Hamaker, De middeneeuwsche keurboeken (supra, n. 21), p., 480 (1410). In Leiden, since 1508 willige panding is mentioned in the Keurboeken. This was a conventional pledge. Execution of such a pledge was allowed only with cooperation from the schout and it corresponded largely to the regular panding. See Hamaker, De middeneeuwsche keurboeken (supra, n. 21), p. 337-338 (book 5, ch. 2, s. 11), and p. 429-430 (book 4, s. 48-49). In some towns, a distinction was made between a regular besetting and a 'simple' besetting. The latter had most probably evolved out of thoonpand. It entailed the locking of assets but without preliminary consent from the city government. However, it differed from thoonpand in that subsequent authorization was required in any case. See A. Telting, Oude rechten van 's Gravenzande, Verslagen en Mededelingen ovR, 4 (1903), p. 377 (dating from 1448).

32 Instructie vanden Hove van Holland, Zeelant ende Vrieslant geordonneert by dye K.M. int jaar 1531, s.l. 1531, s. 124. Only when a judgment of the Court of Holland concerned an obligation to do something, gijzeling was the normal method of enforcement of the judgment. This was not imprisonment, but rather compulsory presence at an inn during a certain period of time. See L.J. van Apeldoorn, Uit de practijkvan het Hof van Holland in de tweede helft van de zestiende eeuw, Utrecht 1938, p. 132-133 (dating between c. $155^{\circ}$ and c. 1570).

33 Zuijderduijn, Medieval capital markets (supra, n. 2), p. 217.

34 Pos, Hypotheek op roerend goed (supra, n. 6), p. 129-130. 
In the second stage of developments, when non-ratified debts were considered eligible for panding proceedings, the aldermen's certificates of debt and debts that were listed in the local laws as being special took on another purpose. Ratified contracts and listed debts could henceforth be enforced by way of accelerated proceedings, resulting in the public sale of sequestrated assets $^{35}$. In the sixteenth century the normal panding proceeding still entailed procedural adjournments of several weeks ${ }^{36}$. But in sixteenth-century Amsterdam, debts up to twelve guilders were considered eligible for enforced sequestration without a formal proceeding, even if they had not been written into an aldermen's judgment or certificate ${ }^{37}$. Sometimes also the unpaid seller had the privilege of an accelerated proceeding ${ }^{38}$. Usually fast-track proceedings were not a variety of thoonpand. Control ex post by the officials of the city was commonly imposed ${ }^{39}$.

When considered together with the source materials concerning the unpaid seller's position, the mentioned rules invite for the conclusion that, at first, in the thirteenth and fourteenth centuries, in many parts of Holland the unpaid seller's debt was regarded as a special debt, listed in legislation, which could be enforced through panding even without a debt certificate or judgment on the sale. Later, in a second stage, from the middle of the 1400 onwards, when panding became more accessible, the unpaid seller was granted access to swifter proceedings of sequestration. These accelerated proceedings were an excep-

35 E.g. Willekeuren Amsterdam 1597 (supra, n. 27), p. 129 (s. 5) (1570), speaking of 'parate executie', which refers to swift executory proceedings. This rule applied to 'schepenkennis$s e n$, i.e. aldermen's certificates, for which a general pledge on all the debtor's assets was presumed. See also J. Wagenaar, Amsterdam, in zyne opkomst, aanwas, geschiedenissen, voorregten, koophandel, gebouwen, kerkenstaat, schoolen, schutterye, gilden en regeeringe, Amsterdam 1760-1767, X, p. 114.

36 For example, in Gouda and Schiedam: L.M. Rollin Couquerque and Q. Meerkamp van Embden, Rechtsbronnen der stad Gouda, Den Haag 1917, p. 659-66o (dating from c. 1570); Heeringa, Rechtsbronnen der stad Schiedam (supra, n. 17), p. 96-97 (Keurboek Schiedam 1556, ch. 7).

37 Wagenaar, Amsterdam (supra, n. 35), X, p. 104-105.

38 Wagenaar, Amsterdam (supra, n. 35), x, p. 101. Most probably this was also the case in early sixteenth-century Delft: Soutendam, Keuren en ordonnantiën (supra, n. 17), p. 15 (s. 6), and p. 37 (s. 1)

39 In Amsterdam, 'parate executie' was not an extrajudicial method of debt enforcement. Also in early sixteenth-century Delft, debts below twenty stuiver mentioned in aldermen's certificates, and most probably also the special debts of restaurant tickets, sale, salaries and fines, were enforceable without panding, but with cooperation of a messenger of the city. But since pandkeering (i.e. opposition by the debtor under seizure) was possible, resulting in court proceedings, this was not an extrajudicial tactic. See Soutendam, Keuren en ordonnantiën (supra, n. 17), p. 37 (s. 1). 
tion to the general, cumbersome, procedural rules of debt enforcement through panding ${ }^{40}$.

In both mentioned stages, the earlier tradition persisted of considering rights on assets as liens, i.e. as prioritized claims not based on an absolute title, rather than as real rights. Even though provisions of collateral were inserted into deeds, private contracts and certificates, they were not thought of as granting rights vis-à-vis third parties. The pledgee of a non-possessory pledge of movables could only lock the pledged assets if they were found with the debtor ${ }^{41}$, even if the clause provided that seizure was possible 'anywhere'42. A fortiori this applied to the unpaid seller, who did not have an express conventional pledge on the assets delivered. One exception to the restrictions on tracing applied for stolen goods. In the 1245 Haarlem city charter for example it was provided that the owner could reclaim, even take his stolen goods from any holder ${ }^{43}$. Furthermore, a provision of collateral entitled the pledgee to a higher rank at the distribution of proceeds ${ }^{44}$. But he was nonetheless considered a competing creditor. This meant that the pledgee was not given the pledged assets themselves, but only what they yielded at a public sale ${ }^{45}$. Moreover, the pledgee shared in the costs of sequestration and executory proceedings; his action of recovering the assets under pledge was not considered a private, extrajudicial remedy. The same applied for the unpaid seller if his debt was listed in laws as a special, preferential debt ${ }^{46}$.

$40 \quad$ Heeringa, Rechtsbronnen der stad Schiedam (supra, n. 17), p. 98 (Keurboek Schiedam (1556), ch. 7, s. 8).

41 De Blécourt and Fischer, Kort begrip (supra, n. 15), p. 248 (no 174 a); Pos, Hypotheek op roerend goed (supra, n. 6), p. 131, p. 145; Planitz, Die Vermögensvollstreckung (supra, n. 18), p. 274; van Hoof, Generale zekerheidsrechten (supra, n. 5), p. 89. See Van Apeldoorn, Uit de practijk (supra, n. 32), p. 246-247.

Planitz, Die Vermögensvollstreckung (supra, n. 18), p. 282, footnote 14 (citing a 1295 Holland-Zeeland deed); Pos, Hypotheek op roerend goed (supra, n. 6), p. 129-130.

43 Hoogewerf, Het Haarlemse stadsrecht (supra, n. 19), appendix 1, p. 16-17 (s. 44).

44 M.D. Osinga and W.S. Gelinck, Kenningboek der stad Leiden 1570-1580, Den Haag 1928, I, p. 139-140 (August-November 1571, a general collateral precedes over older annuities).

45 This applied for all pandingen of movables, see Hamaker, De middeneeuwsche keurboeken (supra, n. 21), p. 423-424 (book 4, s. 36, dating from 1545). As for the unpaid seller: Heeringa, Rechtsbronnen der stad Schiedam (supra, n. 17), p. 98 (Keurboek Schiedam 1556, ch. 7, s. 8).

46 This can be deduced from sections of municipal bylaws regarding panding of movables, which did not distinguish between pledge and other debts. See Hamaker, De middeneeuwsche keurboeken (supra, n. 21), p. 423-424 (book 4, s. 36, dating from 1545, stipulating that if the schout took over the pledge he had to reimburse the creditor for the debt and costs). Moreover, in sixteenth-century Amsterdam it was a rule of municipal law that unpaid sellers that had delivered a ship were considered preferential creditors with regard to that 
Admittedly, there are some examples of rules that allowed for tracing of special non-possessory pledges, but they were defined strictly and reserved for specific assets. In sixteenth-century Amsterdam, and maybe elsewhere in Holland as well, a waterbrief (i.e. an acknowledgment of debt for the sale of a ship) encompassed a 'speciaal verband' (obligatio specialis). The author of a summary of local rules that were applied in Holland and which dates from between $c .155^{\circ}$ and $c .1570$ mentions this rule after a reference to the unpaid seller's debt as being preferential. It seems that the author conveyed the message that tracing against third holders of the ship was possible on the basis of a waterbrieft7.

The academization of sale, insolvency, seizure proceedings and pledges (c.1400-c. 1600)

Since the early fifteenth century, the abovementioned rules and proceedings became more intermingled with academic concepts and ideas than had been the case before that time. First was the conception of the seller's lien as being rooted in the contract of sale. A second development related to the pooling of debts at insolvency proceedings. Thirdly, seizure proceedings were recalibrated to third-party seizures (derdenbeslag, garnishee). The first two approaches were - at least partially - copied from the academic doctrine of Roman law. The second and third developments were loosely related to commercial practice as well. Moreover, the third phenomenon ensued from interactions between princely laws, procedural regulations of higher courts and local proceedings, and it was closely linked to a new trend of substituting claims for proceeds (under 3.5).

\subsection{The contractual nature of the seller's lien}

In the course of the 1400 s and 1500s, throughout the Low Countries the unpaid seller's lien became rooted in an agreement, or a provision in the written contract, stipulating that the seller had to be paid 'à contant' ('met gereeden gelde', i.e. prompt payment). Examples are in the 1429 charter of Zierikzee ${ }^{48}$ and the 1495 charter of Zeeland ${ }^{49}$. Also in the province of Holland this came to be ap-

ship. See Van Apeldoorn, Uit de practijk (supra, n. 32), p. 246 (dating from between c. $155^{\circ}$ and $c .1570$ ).

47 Van Apeldoorn, Uit de practijk (supra, n. 32), p. 246-248.

48 W. Bezemer and A.S. de Blécourt, Rechtsbronnen van Zierikzee, Den Haag 1908, p. 133 (keur 1429, s. 48).

49 R. Fruin, De keuren van Zeeland, Den Haag 1920, p. 219 (ch. 2, s. 34). 
plied $^{50}$. This new approach corresponded with the abovementioned trend of considering collateral rights on assets as either contractual or judicial. Since extrajudicial seizure proceedings had largely been replaced with prejudicial and judicial sequestrations, parties involved in sales secured their rights by adding provisions to the contract of sale. However, at first, the administrators of cities reacted against these practices. Urban governments aimed at preventing lawsuits that could easily be avoided if sellers extended credit at their own risk. In Leiden, for example, in 1521 it was decided that no trials could be waged regarding sales on 'weekgeld', i.e. if payment through weekly instalments was agreed upon, and delivery had taken place before complete payment ${ }^{51}$. Cash deliveries were clearly preferred.

Notwithstanding this, the provision 'à contant' referred to legal doctrine as well and contractual practice prevailed over the actions of aldermen of cities, who slowly altered their positions. The texts of Roman law established that the assets in a sale 'passed' to the buyer only after he paid the price or otherwise satisfied the seller, but also if the seller 'had faith' ('fidem habere') in the buyer even without any payment (D. 18,1,19). In another fragment, the expression 'in creditum abire' ('to extend credit') is used for the latter situation (D. 14,4,5,18). Moreover, the Institutes (Inst. 2,1,41) provided that the buyer 'acquired' delivered merchandise only at the payment of the price or the giving of a security, and that in case this did not take place the buyer 'acquired' them nonetheless if the seller 'followed the faith' of the buyer.

These texts were analyzed and interpreted by the civil lawyers of the twelfth and thirteenth centuries. In doing so, the glossators proffered different opinions over whether delivery without payment was the same as 'fidem habere' or 'in creditum abire'. In the Magna Glossa of Accursius (c. $1263 \mathrm{AD}$ ), the latter came to the conclusion that any sale in combination with delivery at which the price was not paid entailed 'fidem habere', even without an express agreement on this issue ${ }^{52}$. Also, Accursius did not in any case consider the claim of the

50 See for example, Rollin Couquerque and Meerkamp van Embden, Rechtsbronnen der stad Gouda (supra, n. 36), p. 489-49o (20 March 1492); Heeringa, Rechtsbronnen der stad Schiedam (supra, n. 17), p. 48 (June 1497).

$5^{1} \quad$ Hamaker, De middeneeuwsche keurboeken (supra, n. 21), p. 331 (book 5, part 2, s. 36, dating from 10 June 1521). See also Gouda, where in 1523 and 1525 it was decided that sales 'à contant' had to be paid in full within a certain short time after delivery. See Rollin Couquerque and Meerkamp van Embden, Rechtsbronnen der stad Gouda (supra, n. 36), p. 531 (February 1523 ns), and p. 539-540 (3 March 1525 ns).

$5^{2}$ On the debates among the glossators, see K. Luig, Übergabe und Übereignung der verkauften Sache nach Römischem und gemeinem Recht, in: J.A. Ankum e.a. (eds), Satura Roberto Feenstra sexagesimum quintum annum aetatis complenti ab alumnis collegis amicis oblata, Freiburg 1985, p. 445-461, at p. 448-454. 
unpaid seller on delivered merchandise as a real right. He sometimes categorized the unpaid seller's claim as being 'in personam', even though he mostly explained the mentioned Roman-law fragments as dealing with ownership ('dominium' $)^{53}$. Accursius argued that the transfer of ownership at delivery could be prevented if it was agreed or provided that the sale was 'for ready money' ('pro parata pecunia') ${ }^{54}$.

Controversies amongst the glossators and commentators revolved around which regime - 'fidem habere' or 'pro parata pecunia' - was the default one, which was applicable when there had been no agreement. In contrast to Accursius, Baldus (later fourteenth century), for example, held that, by default, the unpaid sale for delivered assets was presumed to be 'for ready money', unless a term of payment was set ${ }^{55}$. Baldus stressed the unpaid seller's claim as being a real right, with the terms 'quasi pignus' and 'dominium'56. The mentioned controversies most probably provided an incentive for local legislators in Holland to issue bylaws on the matter. However, in spite of the influence of academic terminology in contractual practice ('pro parata pecunia' equals 'met gereeden gelde') in the fifteenth century and for a large part of the sixteenth century, in local forensic practice the unpaid seller's lien was not based on retained ownership (see below, under 3.5).

It is telling that notwithstanding the complexity of the academic views on sale and ownership, they were incrementally - yet incompletely - embraced and applied in the forensic and legislative practice of towns. In February 1531, for example, a municipal bylaw of the city of Amsterdam provided that an unpaid seller who negotiated prompt payment was allowed to claim his delivered assets from the buyer if there was a subsequent sign of upcoming default ${ }^{57}$. The Leiden government did allow sales on credit after some time as well ${ }^{58}$.

53 Luig, Übergabe und Übereignung (supra, n. 52), p. 451-454.

54 See the Gloss to D. $14,4,5,18$, s.v. 'Vendicare', D. 18,1,19, s.v. 'Satisfactione', Inst. 2,1,41, s.v. 'Fidem emptoris'.

55 Baldus de Ubaldis, In secundam Digesti Veteris partem Commentaria, Venetiis 1586, 85v (ad D. 13,7,3).

$56 \quad$ Feenstra, De Romeinsrechtelijke prijsbetalingsregel (supra, n. 6), p. 881; Feenstra, Eigendoms-overgang bij koop (supra, n. 6), p. 136; Feenstra, Reclame en revindicatie (supra, n. 6), p. 268-273.

Willekeuren Amsterdam 1624 (supra, n. 26), p. 108; 29, Handvesten (infra, n. 62), II, 502 (6 February 1531 (ns)). See for a discussion, Feenstra, Reclame en revindicatie (supra, n. 6), p. 162-164. The bylaw is commonly cited as dating from 1530, but there is no indication that the New Year's style in lieu of the Easter style was applied.

$5^{8}$ A.S. de Blécourt and J.J.A. Wijs, Kenningboek der stad Leiden 1553 / 1570, Utrecht 1936, p. 139-140 (17 June 1566). 
In Amsterdam, the unpaid seller's lien was considered a special debt, which - even if it had not been ratified before the aldermen - gave access to the debtor's assets by way of swift proceedings. This is reflected in a bylaw of 1522 allowing the unpaid seller who had sold without express credit to lay arrest on the delivered assets with the buyer, in a swift proceeding. A fast-track proceeding, not the general 'panding', was to be followed ${ }^{59}$. One can presume that after February 1531 (see above), the unpaid seller had to refer to a contractual provision 'à contant'; otherwise, it was assumed that his rights were forfeited. There are indeed indications that around mid-century at Amsterdam the seller of a ship who had not been paid in full at delivery, and had not made arrangements in the contract, had no claim of compensation for lack of or partial payment ${ }^{60}$. In the 1522 bylaw, the accelerated proceeding of enforcing unpaid sales was defined as pertaining to the 'zeevaerdigen recht' (i.e. 'seafaring law'), which referred to provisions of a charter of the Count of Holland of 1404 that had imposed an accelerated execution of debts for a.o. 'seafaring' assets (i.e. ships and cargo), and which had imposed fast-track court proceedings for mariners and merchants ${ }^{61}$.

All in all, the mentioned framing of the seller's lien as a contractual and special debt enforced the older idea that seizures could only concern the debtor's belongings; they were not to be extended to third parties. The seller's rights were, now on the basis of the contract, thought of as being restricted, but nonetheless giving access to those assets that were found with his contractual party. Construing the unpaid seller's lien as a matter of contract meant that his position was not considered different from the non-possessory pledgee, even though there were some examples of special non-possessory pledges of movables that procured the pledgee with a right of tracing (see the example of the waterbrief, under 2). The unpaid seller retrieved delivered merchandise with the defaulting buyer; if the latter had sold them, they were out of the unpaid seller's reach.

59 Willekeuren Amsterdam 1624 (supra, n. 26), p. 107 (13 August 1522). Another example is Heeringa, Rechtsbronnen der stad Schiedam (supra, n. 17), p98 (Keurboek Schiedam 1556, ch. 7 , s. 8).

6o Van Apeldoorn, Uit de practijk (supra, n. 32), p. 246-247 (dating between c. 1550 and c. 1570).

$61 \quad$ Willekeuren Amsterdam 1597 (supra, n. 27), p. 38-39. In 1531, the Amsterdam aldermen also decided that the period of 'naesting' (i.e. pre-emption by relatives), which made executory proceedings lengthy, was to be reduced to 24 hours for ships. See Willekeuren Amsterdam 1624 (supra, n. 26, 106 (10 January 1531 ns). 


\begin{tabular}{|c|c|c|c|c|}
\hline Periods & Nature & Effect & $\begin{array}{l}\text { System of } \\
\text { conveyance }\end{array}$ & $\begin{array}{l}\text { Requirements for } \\
\text { the lien }\end{array}$ \\
\hline $\begin{array}{l}c 1300-c 1400 \\
\text { (local law) }\end{array}$ & $\begin{array}{l}\text { debt }(\text { in } \\
\text { personam })\end{array}$ & $\begin{array}{l}\text { exemption of } \\
\text { requirements for } \\
\text { executory } \\
\text { proceedings }\end{array}$ & delivery & $\begin{array}{l}\text { delivery, } \\
\text { incomplete } \\
\text { payment }\end{array}$ \\
\hline $\begin{array}{l}c \text { 1400-c } 1560 \\
\text { (local law, } \\
\text { provincial } \\
\text { courts) }\end{array}$ & $\begin{array}{l}\text { debt (in } \\
\text { personam) }\end{array}$ & $\begin{array}{l}\text { preferential debt, } \\
\text { access to swift } \\
\text { executory } \\
\text { proceedings }\end{array}$ & delivery & $\begin{array}{l}\text { delivery, } \\
\text { incomplete } \\
\text { payment, } \\
\text { clause 'á contant' }\end{array}$ \\
\hline $\begin{array}{l}\text { c } 1560-c 1630 \\
\text { (local law, } \\
\text { provincial } \\
\text { courts, doctrine) }\end{array}$ & $\begin{array}{l}\text { debt, traces of } \\
\text { real right } \\
\text { (ownership, } \\
\text { quasi pignus) }\end{array}$ & $\begin{array}{l}\text { preferential debt, } \\
\text { access to swift } \\
\text { executory } \\
\text { proceedings }\end{array}$ & delivery & $\begin{array}{l}\text { delivery, } \\
\text { incomplete } \\
\text { payment, } \\
\text { clause 'à contant' }\end{array}$ \\
\hline $\begin{array}{l}c \text { 1630-c 166o } \\
\text { (doctrine: Grotius) }\end{array}$ & $\begin{array}{l}\text { reservation of } \\
\text { ownership } \\
\text { (in rem) }\end{array}$ & $\begin{array}{l}\text { superpriority (?), } \\
\text { extensive tracing }\end{array}$ & $\begin{array}{l}\text { delivery (yet } \\
\text { actually payment } \\
\text { unless clause "on } \\
\text { credit") }\end{array}$ & $\begin{array}{l}\text { delivery, } \\
\text { incomplete } \\
\text { payment }\end{array}$ \\
\hline $\begin{array}{l}c \text { 163o-c 166o } \\
\text { (local law) }\end{array}$ & $\begin{array}{l}\text { reservation of } \\
\text { ownership } \\
(\text { in rem })\end{array}$ & $\begin{array}{l}\text { superpriority (?), } \\
\text { extensive tracing }\end{array}$ & delivery & $\begin{array}{l}\text { delivery, } \\
\text { incomplete } \\
\text { payment, } \\
\text { clause 'à contant' }\end{array}$ \\
\hline $\begin{array}{l}c \text { 166o-c 168o } \\
\text { (doctrine: Van } \\
\text { Leeuwen) }\end{array}$ & $\begin{array}{l}\text { reservation of } \\
\text { ownership } \\
\text { (in rem) }\end{array}$ & no tracing & delivery & $\begin{array}{l}\text { delivery, } \\
\text { incomplete } \\
\text { payment }\end{array}$ \\
\hline $\begin{array}{l}c 1660-c 1730 \\
\text { (local law) }\end{array}$ & $\begin{array}{l}\text { reservation of } \\
\text { ownership } \\
\text { (in rem) }\end{array}$ & $\begin{array}{l}\text { preferential debt, } \\
\text { limited tracing }\end{array}$ & delivery & $\begin{array}{l}\text { delivery, } \\
\text { incomplete } \\
\text { payment, } \\
\text { clause 'à contant' }\end{array}$ \\
\hline $\begin{array}{l}\text { c 1680-c } 1730 \\
\text { (doctrine: Voet, Van } \\
\text { der Keessel, Van } \\
\text { Bijnkershoek) }\end{array}$ & $\begin{array}{l}\text { reservation of } \\
\text { ownership } \\
\text { (in rem) }\end{array}$ & $\begin{array}{l}\text { preferential debt, } \\
\text { limited tracing }\end{array}$ & $\begin{array}{l}\text { delivery (yet } \\
\text { actually payment } \\
\text { unless clause 'on } \\
\text { credit') }\end{array}$ & $\begin{array}{l}\text { delivery, } \\
\text { incomplete } \\
\text { payment }\end{array}$ \\
\hline
\end{tabular}

Schematic overview of the legal approaches toward the seller's lien ( $c$ 1300- $c$ 1730) 


\begin{tabular}{|c|c|c|}
\hline Periods & Nature & Effect \\
\hline$c$ 1300-c 1400 (local law) & debt (in personam) & priority, no tracing \\
\hline c 1400-c 156o (local law) & $\begin{array}{l}\text { debt, connotations } \\
\text { of real right }\end{array}$ & $\begin{array}{l}\text { priority, no tracing for general } \\
\text { pledges, tracing for some } \\
\text { special pledges }\end{array}$ \\
\hline $\begin{array}{l}c 1560-c 1630 \text { (local law, provincial } \\
\text { courts, doctrine) }\end{array}$ & $\begin{array}{l}\text { debt, connotations } \\
\text { of real right }\end{array}$ & $\begin{array}{l}\text { priority, no tracing for general } \\
\text { pledges, tracing for some } \\
\text { special pledges }\end{array}$ \\
\hline$c$ 1630-c 166o (doctrine: Grotius) & $\begin{array}{l}\text { debt, connotations } \\
\text { of real right }\end{array}$ & priority, limited tracing \\
\hline c 1630-c 166o (local law) & $\begin{array}{l}\text { debt, connotations } \\
\text { of real right }\end{array}$ & priority, limited tracing \\
\hline $\begin{array}{l}\text { c 166o-c } 1730 \text { (doctrine: Van } \\
\text { Leeuwen, Voet, Van der Keessel, Van } \\
\text { Bijnkershoek) }\end{array}$ & $\begin{array}{l}\text { debt, connotations } \\
\text { of real right }\end{array}$ & priority, limited tracing \\
\hline c 166o-c 1730 (local law) & $\begin{array}{l}\text { debt, connotations } \\
\text { of real right }\end{array}$ & priority, limited tracing \\
\hline
\end{tabular}

Schematic overview of the legal approaches toward movable non-possessory pledge ( $c$ 1300$c$ 1730)

\subsection{Rateable distribution in insolvency proceedings}

From the middle of the fifteenth century onwards, authorities of cities in Holland started imposing a sharing of risk among creditors of an insolvent debtor. At first, this only concerned creditors with ratified debts. After some time, in the course of the later fifteenth and sixteenth centuries, the legislators considered also notarial deeds and private agreements as sufficient evidence of debts in collective insolvency proceedings. From that moment onwards, all creditors, having ratified or private debts, were summoned upon the bankruptcy of their communal debtor. The proceeds of the public sale of his assets were distributed first according to the prior tempore rule, for aldermen's certificates and judgments ${ }^{62}$, and then, for the other creditors, equally but with rateable deductions

62 Soutendam, Keuren en ordonnantiën (supra, n. 17), p. 24-25 (s. 25), and p. 52-53 (s. 4). In early sixteenth-century Delft, the rule was that debt certificates corroborating private written agreements and instruments were given priority over debt certificates that were not based on such documents. 
on their claims ${ }^{63}$. It is evident that this pooling of debts referred to the process of generalization of debts in procedural rules on evidence, as well as to the growing popularity of private debt instruments; but also, the rules relating to rateable distributions upon insolvency were based on Romanist doctrine ${ }^{64}$. A policy consideration underlying legal reform was that the risk of insolvency had to be spread over all unsecured creditors.

The change in the conceptions of executory and seizure proceedings, as being collective in case of bankruptcy, meant that the earlier rules regarding ratified and listed debts were now applied onto questions of priority. Because the right of the seller to reclaim his delivered assets was linked to a contractual provision, he was not considered an owner, or the holder of a real right. Instead, his claim competed with those of other creditors, but was nonetheless preferential. The unpaid seller was paid out first, or before other creditors with unsecured debts. Yet at the same time, the massa of the insolvent estate encompassed the assets delivered by the seller, as well as all other assets that had been left behind by the fugitive debtor. Therefore, the unpaid seller was not considered as a 'separatist' super-priority creditor. For Holland, this was seldom explicitly mentioned in texts of municipal law. However, in sixteenthcentury Antwerp, where many of the abovementioned developments had taken place between approximately 1470 and $155^{0}$, in the 1520 s it was stated expressly that the unpaid seller was given priority as competing creditor, not as 'separatist' creditor, if - and only if - the sale had been made 'à contant ${ }^{65}$.

63 Hamaker, De middeneeuwsche keurboeken (supra, n. 21), p. 426 (book 4, s. 40, dating from 1545); H. Planitz, Studien zur Geschichte des deutschen Arrestprozesses, Zeitschrift der Savigny-Stiftung für Rechtsgeschichte. Germanistische Abteilung, 34 (1913), p. 49-140, 39 (1918), p. 223-308, and 40 (1919), p. 87-198; Willekeuren Amsterdam 1624 (supra, n. 26), p. 108 (sixteenth century); Handtvesten, ofte privilegien, handelingen, costumen ende willekeuren der Stadt Aemstelredam ..., Amsterdam 1639 (hereinafter Willekeuren Amsterdam 1639), p. 100 (sixteenth century).

64 W. Pakter, The origins of bankruptcy in medieval Canon and Roman law, in: P. Linehan (ed.), Proceedings of the Seventh International Congress of Medieval Canon Law, Vatican City 1988, p. 485-506, at p. 498-499; U. Santarelli, Per la storia del fallimento nelle legislazioni italiane dell'età intermedia, Padua 1964, p. 238-242.

65 D. De ruysscher, De ontwikkeling van het Antwerpse privaatrecht in de aanloop naar de costuymen van 1548, Uitgave van het Gulden Boeck (ca. 1510 - ca. 1537), (projecten van) ordonnanties (1496 - ca.1546), een rechtsboek (ca. 1541 - ca. 1545) en proeven van hoofdstukken van de costuymen van 1548, Handelingen van de Koninklijke Commissie voor de Uitgave der Oude Wetten en Verordeningen van België, 54 (2013), p. 65-324, at p. 140 (s. 83), and p. 141 (s. 87). See also G. De Longé (ed.), Coutumes du pays et duché de Brabant, Quartier d'Anvers: Coutumes de la ville d'Anvers, Brussels 1870-1878, I, p. 404 and p. 406. 


\subsection{Third-party seizure proceedings (derdenbeslag, garnishee)}

Another important phenomenon concerned third-party seizures. They developed over the course of the fifteenth century. Early traces are found in the forensic practice found within the cities of Holland. In mid-fifteenth-century Leiden, it was possible to sequestrate assets of a debtor with one of his contractual parties. In that case the debtor was forced to have the attachment lifted because he experienced pressure from the third party with whom assets were locked. In fifteenth-century Leiden the proceedings mentioned only involved non-citizens. They could be based on non-ratified debts as well ${ }^{66}$. A century later, the quality or citizenship of the debtor or the third party under seizure was no longer considered relevant ${ }^{67}$. This development went together with the acknowledgment of certain rights for third parties that were affected. At the level of the Court of Holland, the procedural regulations of the sixteenth century left more possibilities for outsiders and persons under seizure to contest seizures. Usually, in the early sixteenth century, seizure proceedings in the Court of Holland were combined with a 'mandement van arrest', which was a court-imposed authorization to attach the effects of a debtor ${ }^{68}$. A judgment of the court could be enforced as well, which was considered 'executie'. As early as 1531, both arrest and executie could be opposed by third parties, under seizure or when having interests otherwise ${ }^{69}$. There are traces of third-party seizures that were confirmed by the Court of Holland in the $158 \mathrm{os}^{70}$.

These proceedings were early on filled in with concepts of substantive Roman law as well. For example, in the early seventeenth-century Court of Holland opposition resulted in the lifting of the attachment in case the third party

66 Blok, Leidsche rechtsbronnen (supra, n. 17), p. 167 (fifteenth century, third-party seizure, without mention of debt certificates), and p. 199 (fifteenth century, third-party seizure on the basis of a certificate of debt). See also A. Nortier, Bijdrage tot de kennis van het burgerlijk proces in de 15 de eeuw binnen de stad Leiden, Leiden 1874, p. 25.

67 De Blécourt and Wijs, Kenningboek der stad Leiden $1553 / 1570$ (supra, n. 58), p. 5 (September 1553, seizure of money, proceeds of a sale of immovable property), p. 49 (June 1556, seizure of money, proceeds of a sale of a mill stone), and p. 130 (July 1565, seizure of assets, revindication of share out of an inheritance). See also Hamaker, De middeleeuwsche keurboeken (supra, n. 21), p. 438 (book 4, s. 67, dating from 1545). This keurboek of 1545 is the first bylaw mentioning seizures of assets with holders not being debtors.

68 J. Hallebeek and C.H. van Rhee, Praxis et ordo iudiciorum curiae Hollandiae, De stijl van het Hof van Holland in de traditie van het ius commune, Verslagen en mededelingen ovr, nieuwe reeks, 10 (1999), p. 95 (early seventeenth century).

69 Hallebeek and van Rhee, Praxis et ordo (supra, n. 68), p. 74-75, and p. 95-96; Instructie $153^{1}$ (supra, n. 32), s. 177 .

70 C. Neostadius, Utriusque Hollandiae, Zelandiae, Frisiaeque Curiae Decisiones ..., Hagae Comitis 1667, p. 116 (decisio 45, dating from around 1584). 
under seizure, or anyone else, proved his ownership ${ }^{71}$. The result of this rule was that third-party seizures were not used if it was expected or feared that the holder of the assets could prove his ownership. Since third-party seizures then concerned parties under seizure that could only invoke contractual rights, it became normal practice that the debtor responded on their behalf ${ }^{72}$.

It is clear that this ensued from the reception of academic approaches and the blend of ownership with seizure proceedings because before the seventeenth century this had not always been the case. Leiden's forensic practice is a case in point. In the 1545 Leiden keurboeken, as had been the case in the earlier regulations of the Court of Holland, it was stipulated that seizure of assets with holders, not being the debtors themselves, could be contested by those possessors ${ }^{73}$. However, in practice, the person with whom the seizure was laid could choose whom to send to court. In April 1568, three merchants from The Hague laid attachment on a party of wool at the Hospital of Saint-Barbara in Leiden. This wool had been brought there by Cornelis Adriaens, a brewer, in the course of a contract of commodatum that had been negotiated with Vranck Willems. The latter had received the wool from Henrick Allerts, following a sale from the claimants. The defendant at the trial was Cornelis Adriaens, who was not the buyer of the wool or the party under seizure. He brought up arguments on behalf of the buyers who did not stand on trial. Adriaens stated that the wool under seizure was not the wool that had been sold by the The Hague merchants, but Scottish wool that had been bartered for their party of wool. In spite of the absence of both the debtor and the third party under seizure in court, the Leiden aldermen judged that the third-party seizure was legitimate ${ }^{74}$. Moreover, this trial demonstrates that the creditors did not so much frame their claim as a reivindicatio of their party of wool, but rather as a matter of debt for which the third-party seizure served as means of pressure. As for any proceeding of seizure, the ensuing public sale was only initiated if the debtor did not pay up for the debt. In the mentioned case, it is unclear what happened in this regard.

71 In 1531, opposition was open to all those alleging 'ownership or claims', even 'by adventure'. See Instructie 1531 (supra, n. 32), s. 177. However, in the early seventeenth century it was only when ownership was evidenced that the seizing creditor had to lift the attachment and seek seizure of other assets. See Hallebeek and van Rhee, Praxis et ordo (supra, n. 68) , p. 95-96.

Pieter Bort, Tractaet handelende van arresten, in: Pieter Bort, Alle de wercken ..., 's Gravenhage 1688, p. 65 (part 5, no 12).

73 Hamaker, De middeneeuwsche keurboeken (supra, n. 21), p. 438-439 (book 4, s. 47).

74 De Blécourt and Wijs, Kenningboek der stad Leiden 1553 / 1570 (supra, n. 58), p. 170-172 (26 April 1568). 
It is probable that the proceeding of third-party seizure was a good fit if entangled commercial relations were at stake. Creditors could identify those merchants within their debtors' networks that were most creditworthy. The flexible characteristics of the proceeding added to its attractiveness. This was even increased when the burdens of proof were lowered, once ideas on substitution of claims and encumbered proceeds began to emerge (see under 3.5).

\subsection{Amsterdam v Holland}

In early seventeenth-century Amsterdam, the city's aldermen aimed at preserving their local law against the influence from Roman-Dutch doctrine and central legislation. For instance, they had a preference for the prior tempore rule in pledges. At first in Holland, as well as in Amsterdam, with regard to immovable - and possibly also movable - property the prior tempore rule applied, even in the relation between general and special pledges ${ }^{75}$. But in 1580 the Politieke Ordonnantie established it as rule that later special pledges of immovable property had priority over older general pledges ${ }^{76}$.

The implications of the central legislation were high. Already before 1580 , in 1565 , a princely ordinance had provided that the pledgee of a special non-possessory pledge on immovable property could seek payment from holders, even if they were not debtor ${ }^{77}$. As a result of this legislation, a new distinction arose between general pledges, as encompassing all assets movable and immovable, and special ones, which were concerned with a designated immovable. Before 1565 the notion 'speciaal verband' - a translation of 'obligatio specialis' - had commonly been used for the general non-possessory pledge, thus also referring to pledges on movables ${ }^{78}$. After 1565 , the new rules most probably resulted in the virtual disappearance of special non-possessory pledges on movables, which before that time seem to have been unpopular as well ${ }^{79}$. There are indications that non-possessory pledges were thenceforth usually general ${ }^{80}$. The reason for this may have been the legislative restriction of the meaning of 'special pledges' to pledges of immovable property; special non-possessory pledges

75 Neostadius, Utriusque Curiae Decisiones (supra, n. 70), p. 91 (decisio 25, dating from c. 1579). See also Van Apeldoorn, Uit de practijk (supra, n. 32), p. 49, and van Hoof, Generale zekerheidsrechten (supra, n. 6), p. 131.

76 S. 35 Politieke Ordonnantie 158o, in: Groot Placcaet-boeck, C. Cau (ed.), 's Gravenhage 1658, I, col. 338-339 (1 April 1580).

77 Groot Placcaet-boeck (supra, n. 76), I, col. 382 (21 February 1565 ns).

78 G. de Cretser, Beschryvinghe van 's-Gravenhage, Amsterdam 1711, p. 83 (12 January 1534 ns).

79 For the Southern Low Countries: Ph. Godding, Le droit privé dans les Pays-Bas méridionaux (12e-18e siècle), Brussels 1987, p. 256-257.

80 M.D. Osinga and W.S. Gelinck, Kenningboek der stad Leiden 1570 / 1580, 's Gravenhage 1928, I, p. 61 (2 February 1572 ns), and p. 126 (22 June 1571). 
of movables were not mentioned in the laws of 1565 and 1580 , which meant that their effects were uncertain. Furthermore, since the legislative variety of general pledge encompassed rights on immovable property, the appeal of nonpossessory pledges that exclusively concerned movables may have been minimal. This especially considering that the dangers of fraud were higher with non-possessory pledges of movables than with non-possessory pledges of immovable property. As a result of the new legislation, rights against third party possessors were granted for the pledgee of a non-possessory special pledge on immovable property ${ }^{81}$. With regard to general pledges, the older rule was maintained that the pledgee was only allowed to seize them if they were in the debtor's hands.

However, notwithstanding the new rules, in 1594 the Amsterdam authorities received approval from the States of Holland to continue applying the prior tempore rule in hypothecs of immovable property; as a result, the older rule that a previous, even general pledge, preceded over a later, even special, pledge was maintained in Amsterdam ${ }^{82}$. When movables were concerned, the earlier approach applied both in Holland and Amsterdam: the oldest pledge had priority over a younger one, even if the latter was for some assets only and the former general ${ }^{83}$. But, as mentioned, after 1565 non-possessory special conventional pledges of movables became rare.

The Amsterdam policies were a reaction against the 1580 Politieke Ordonnantie. It seems that the Amsterdam authorities highly valued their older rules, which had been based on earlier Romanist doctrine (e.g. the prior tempore rule).

This also concerned the rights of the unpaid seller. Late-medieval doctrine had acknowledged a right of reclamation in the case of bankruptcy, even if credit had expressly been granted. It was probably first proposed by Baldus ${ }^{84}$ that the faith of the seller was to be deemed extorted by fraud if the buyer did not intend to pay the price at the moment of the making of the contract. Such a fraudulent intention was presumed if the buyer escaped or was declared

$81 \quad$ Neostadius, Utriusque Curiae Decisiones (supra, n. 70), p. 58-6o (decisio no 16, dating from between $c .1578$ and $c .1583$ ). See also Van Apeldoorn, Uit de practijk (supra, n. 32), p. 44.

82 Groot Placcaet-boeck (supra, n. 76), II, col. 2211-2214 (8 March 1594). See also Willekeuren 1597 (supra, n. 27), p. 129 (s. 8) (1570), and p. 134-136 (8 March 1594). This rule was re-issued in 1661: Noordkerk, Handvesten (supra, n. 30), II, p. 510 (28 November 1661).

83 Consultatien, advysen en advertissementen gegeven ende geschreven bij verscheyden treffelijke rechtsgeleerden in Holland, Rotterdam 1645-1670 (hereinafter Hollandsche Consultatien), II, p. 216-218 (22 November 1612), and I, p. 383-384 (26 May 1631).

84 Baldus de Ubaldis, In secundam Digesti Veteris partem Commentaria, Venetiis 1586 , fol. $85 \mathrm{~V}$ (ad D. 13,7,3), and fol. 95r (ad D. 14,4,5,15). 
bankrupt immediately or soon after receiving the sold assets ${ }^{85}$. In this case, therefore, the delivered merchandise was considered to be encumbered for the seller, even when a clause 'on credit' (also called 'à temps') had been inserted into the contract. The unpaid seller had priority over other creditors. In Antwerp, this academic rule was mentioned for the first time in the 1582 bylaws, and it was repeated in 1608. In 1557 the same rule applied in Haarlem ${ }^{86}$. In Amsterdam, however, where the Antwerp law had some influence, in 1617 a turbe to the contrary was issued: the 'fraud' of the insolvent buyer was not a ground for legal preference of the seller over other creditors if the seller had extended credit ${ }^{87}$. This was clearly an older position than the one that was accepted in Haarlem and Antwerp.

\subsection{Abstracted liens and encumbrances}

As a result of all of the above, in all mentioned periods, the unpaid seller's lien, as well as the pledgee's rights out of a non-possessory pledge of movables, were not so much considered as being real rights, but rather as rights to retrieve, seize and swiftly receive the assets of the debtor. As regards the unpaid seller, the emphasis was on the possibility to sequestrate and auction the delivered assets, not on the unpaid seller's rights vis-à-vis third parties ${ }^{88}$. Therefore, the unpaid seller was considered a competing creditor, not a 'separatist' superpriority creditor. He had to pay for the costs of the executory proceedings, for example. It can be assumed that even in the later sixteenth century the unpaid seller did not generally have a right of tracing on the sold assets against third parties, other than by way of third-party seizure ${ }^{89}$. This was not tracing on the

85 Alexander de Imola (Tartagnus), In primam Infortiati partem Commentaria, Venetiis, Pinzi, 1562, p. 41 (ad D. 24,3,22,13).

86 Huizinga, Rechtsbronnen der stad Haarlem (supra, n. 21), p. 388 (s. 314, dating from 1557).

87 Noordkerk, Handvesten (supra, n. 30), II, p. 505; Willekeuren Amsterdam 1624 (supra, n. 26), I, p. 96 (15 April 1617). Groenewegen cites this document in a note to Grotius' Inleidinghe (2,5,14 (ed. 1657), n. 19). The law in Holland seems to have followed the Antwerp position, which was conform to the ius commune. See Hollandsche Consultatien (supra, n. 83), II, p. 258-259 (4 August 160o).

88 Important was that private seizure was not allowed. See, for pledges, De Blécourt and Fischer, Kort begrip (supra, n. 16), p. 260 (no 182a). Contra: Pos, Hypotheek op roerend goed (supra, n. 6), p. 131, and F.F.X Cerutti, Hoofdstukken uit de Nederlandse rechtsgeschiedenis, Nijmegen 1972, p. 340, but the sources cited do not allow us to ascertain seizure without intervention of the authorities.

89 Indicative are a consilium of 1635 stating that the right of the seller (not dominium but instar pignoris) does only sort effect against the buyer, not against third parties. See Hollandsche Consultatien (supra, n. 83), IV, p. 309-310 (20 February 1635). In his dissertation, Feenstra treats this advice as singularis, but in publications later in his life he re-appraised the seller's lien as being an 'obligation spéciale'. See Feenstra, De 
basis of ownership, but rather a remedy linked to the contractual right of the seller to reclaim delivered merchandise. The addressing of a business contact or client of the debtor pressured the latter to have the attachment lifted as soon as possible.

The new conceptions of third-party seizures in the sixteenth century were also triggered by ideas on encumbered money. Seizures could be laid on 'coins' ('penningen') that had been paid in exchange for the assets under pledge or affected otherwise. Claims were considered as having been substituted. As a result, third-party seizure proceedings could be concerned with proceeds from transactions, as was the case in Leiden in the $155 \mathrm{os}^{90}$. Moreover, near the end of the sixteenth century encumbrances became highly relevant at public auctions. If after the assets were sold publicly, a creditor claimed a share of them, he could lay seizure on the 'coins' that had been paid for them ${ }^{91}$.

There was some doctrinal support for these approaches. Encumbrances on proceeds may have been inspired by contemporary legal doctrine. Academic texts ruled out the executory proceedings of assets, pledged earlier, from a third-party holder in case the latter had received those assets from the debtorpledgor during the course of a trial that had been waged against the latter by the creditor-pledgee. Pursuing a res litigiosa by way of execution of the judgment resulting from the trial against the debtor was only considered possible for an owner, not for a pledgee. Already the Accursian Gloss reports the opinion of 'some (jurists)', who held that a lawsuit over a pledge does not make the thing litigiosa, similarly to a personal action ${ }^{92}$. Therefore, the opinion that a creditor-pledgee could not execute the court sentence on the debtor against a third party possessor prevailed among late-medieval Italian legal scholars,

Romeinsrechtelijke prijsbetalingsregel (supra, n. 6), p. 881; Feenstra, Eigendomsovergang bij koop (supra, n. 6), p. 135-136. Moreover, the 1556 Keur of Schiedam, the 1495 Zeeland keur, as well as the 1429 Zierikzee keur mention the buyer as the seller's opponent, not other parties. See also the 1570 Zierikzee procedural costuymen: the creditor with a pledge in an aldermen's certificate can seize assets 'of the debtor' where he finds them but it is explicitly stated that they must 'pertain' to the debtor. See Bezemer and De Blécourt, Rechtsbronnen van Zierikzee (supra, n. 48), p. 504 (s. 5). We interpret the 1519 Keur of Voorne, which states that the unpaid seller ' $a$ contant' can retrieve the assets 'at any place where he may find them', along the same lines as the 1495 and 1570 Zierikzee regulations. See Keuren ende Privilegien des lands ende heerlijckheyts van Voorne, Rotterdam 1717, p. 85 (s. 51). Contra: Feenstra, Reclame en revindicatie (supra, n. 6), p. 165-166.

90 De Blécourt and Wijs, Kenningboek der stad Leiden 1553 / 1570 (supra, n. 58), p. 5 (September 1553, seizure of money, proceeds of a sale of immovable property), 49 (June 1556, seizure of money, proceeds of a sale of a mill stone).

91 See for Amsterdam, Willekeuren Amsterdam 1624 (supra, n. 26), p. 90 (24 December 1592).

92 Gloss to C. 8,36(37). Auth. Litigiosa Res (= Nov.112.1), s.v. 'Dominio'. (Codicis Iustiniani ex repetita praelectione libri novem priores ..., Lugdunum 1560, p. 1621). 
such as Bartolus ${ }^{93}$, Baldus ${ }^{94}$, and Tartagnus ${ }^{95}$. In the sixteenth century, this was considered to be a commonplace: the creditor-pledgee, like any personal creditor, did not have a right to trace the assets 'under trial' but was to file a new lawsuit against the third party possessor ${ }^{96}$. In the 158 os the Court of Holland stretched this doctrine somewhat by acknowledging that if an amicable ruling was reached on assets that in the meantime had been sold, they could be traced, but only if a special pledge (thus on immovable property) could be proved; general pledges or an earlier contract of sale only entitled to claims on the sums that had come from the (last) sale ${ }^{97}$.

Furthermore, at the roots of encumbrances of money proceeds stood the consignment in court, which was imposed by princely laws starting in the later 1530s. For any claim that was based on bills of exchange, obligaties (bills obligatory) or marine insurance contracts, the debtor was held to consign the claimed sums in the court ${ }^{98}$. As a result, these 'coins' were considered encumbered. In the middle of the sixteenth century, in the Court of Holland this consignment ('namptisatie') was very much identified with claims based upon obligaties and other documents that often contained a 'verband'99.

Resuming all of the above: it is highly probable that in the later sixteenth century non-possessory pledges of movables remained generally untraceable and that they only resorted effect vis-à-vis the debtor. Seizure could be laid on

93 Bartolus de Saxoferrato, Opera omnia, Lugdunum 1552, viII, fol. 117 r (repetitio on C. 8,13,3).

94 Baldus de Ubaldis, In VII, VIII, IX, X \& XI Codicis libros Commentaria, Venice 1599, fol. $154 \mathrm{~V}$ (ad C. 8,36,5).

95 Alexander de Imola (Tartagnus), Commentaria in I \& II Digesti Novi partem, Venice 1620, fol. $144 v$ ( ad D. 42,1,15,4).

96 Didacus Covarruvias a Leiva, Enucleatus et auctus practicis in quaestionibus, Lyon 1688, p. 141 (vers. Posterior vero authoritas, no 40), and p. 142 (vers. Hinc enim deducitur, no 45); Antonius Faber, Codex Fabrianus ..., Geneva 1674, p. 1058 (book 8, ch. 26, def. 8).

97 Neostadius, Utriusque Curiae Decisiones (supra, n. 70), p. 58-6o (decisio no 16, dating from between c. 1578 and c. 1583). See also Van Apeldoorn, Uit de practijk (supra, n. 32), p. 44, and Hallebeek and van Rhee, Praxis et ordo (supra, n. 68), p. 100 (s. 7). According to the latter regulation, a judgment that confirmed an agreement between the litigants did not hamper the rights of creditors of annuities. They were allowed to trace the immovable property in which the annuities were vested.

98 This had been imposed on Antwerp and the Duchy of Brabant in the 1530s. See Recueil des Ordonnances des Pays-Bas, Deuxième série: 1506-1700, C. Laurent et al. (eds), Brussels 18931978, IV, p. 15-16 (7 March 1537 ns), and p. 26-27 (9 May 1537). Namptisatie was practised along the lines of these ordinances in the Court of Holland in the sixteenth century. See P. Merula, Synopsis praxeos civilis, Maniere van procederen ..., Amsterdam 1592, p. 42 (book 2, tit. 2, ch. 2, no 1).

99 Instructie 1531 (supra, n. 32), s. 119; Groot Placcaet-boek (supra, n. 77), col. 1405-1408 (6 November 1564). See also Van Apeldoorn, Uit de practijk (supra, n. 32), p. 40, and p. 154159; Hallebeek and van Rhee, Praxis et ordo (supra, n. 68), p. 86-9o. 
coins that were in one way or another the debtor's, even if they were in the hands of a third party. But again, as was mentioned above, after 1565 special pledges on movables were usually possessory, non-possessory pledges of movables were only general and encompassed therefore both movable and immovable property. Third-party seizures on the basis of encumbrances were therefore most relevant for unpaid sellers. In case the buyer had re-sold the merchandise that he had received, seizure of the merchandise, but also of the proceeds from that sale, was possible. However, when these rules and practices became re-evaluated on the basis of doctrine, they subsequently changed again.

4

Grotius: the seller's lien as ownership

The unpaid seller's lien was generally not considered as entailing tracing, but only priority vis-à-vis other competing creditors. However, it became conceived of as an actio in rem since the 1630 . The first legal author to do so in a consistent way was Grotius. In his Inleidinghe tot de Hollandsche Rechtsgeleertheyt (1631, but written in 1619) he construed the unpaid seller's lien as concerning ownership $(2,5,14 ; 2,15,4)$. He seems to have been influenced by the doctrine of the Commentators, and by Roman law in general (Inst. 2,1,41, see above $)^{100}$. This inspiration is clear in the fact that Grotius states that either payment, surety or pledge $(2,5,14)$, either expressly extended credit $(3,15,4)$ ends the seller's ownership ${ }^{101}$. The latter refers to the 'fidem sequi' in Inst. 2,1,41: if the seller consented with later payment at the concluding of the sale, then he lost his ownership.

Grotius distinguishes the seller's lien, as silent reservation of ownership, from the seller's express reservation of rights by way of pledge $(2,48,29)^{102}$. In the first case, when the sale was not 'à temps', the seller could recover his assets; an agreement 'pro parata pecunia' was thus presumed. For early seventeenthcentury Holland, this was an important shift in legal thought. In fact, the sys-

$100 \quad$ Feenstra, Reclame en revindicatie (supra, n. 6), p. 117-119.

101 See Feenstra, Reclame en revindicatie (supra, n. 6), p. 118-119. Feenstra interpretes the last phrase 'of dat hem de verkooper de selve penningen heeft geborgt' as extension of credit by the seller. The verb 'borgen' is only used once in the Inleidinghe, and that's here. Reading the mentioned fragment as distinguishing between pledge ('den verkooper daer voor zeecker gedaen') and surety ('dat hem de verkooper de selve penningen heeft geborgt') is more consistent with 3,15,4, which distinguishes the extension of credit from the giving of a security ('verzekeren'), which is either a surety or a pledge.

102 Feenstra, Reclame en revindicatie (supra, n. 6), p. 137-138; Koops, Vormen van subsidiariteit (supra, n. 6), p. 135 . 
tem of conveyance of ownership after sale changed because of this change of position. Since the seller's lien was now considered as involving real rights and ownership at sale only passed upon payment, this meant that the earlier 'traditionalist' approach was to a large extent modified. 'Delivery conveys ownership' became 'payment conveys ownership'.

The logical consequence of construing the seller's lien as ownership was that a reivindicatio was possible against third acquirers as well, irrespective of the latter's good faith or their payment of a purchasing price $(2,3,4-5)$. However, Grotius does not envisage this right of tracing in case the seller's lien is based on a contractual provision of pledge, when the holder has received the assets on a legitimate basis $(2,48,29)$. But Grotius mentions an exception. He states that in the bailiwick of Rijnland the rule applies that the unpaid seller-pledgee can pursue a third party for the assets under pledge, even if the acquirer had received them on the basis of a lawful title $(2,48,29)^{103}$.

The reference to the Rijnland rule is curious. The bailiwick of Rijnland constituted the Northern part of Holland, with Leiden as capital and to which Amsterdam belonged. However, at the beginning of the seventeenth century neither of these cities applied the landrecht of Rijnland in matters of pledge and executory proceedings. Their municipal law was a lex specialis ${ }^{104}$. Moreover, Grotius over-interpreted the bylaws of the bailiwick, which date from 1570. They stipulate the late-medieval rule that the pledgee of a 'speciaal verband' on assets sold and delivered, provided in an acknowledgment of debt

103 This passage is difficult to understand. It has been interpreted in two ways. One interpretation presumes that the Rijnland exception concerns the form of the pledge: according to Van der Keesel it means that in Rijnland informal pledges for the seller (i.e. the delivery in combination with a reservation of title as pledge, neither of which were ratified) were sufficient to trace the assets with third parties. A contrario this meant - according to Van der Keessel - that outside of Rijnland, in Holland, informal pledges were not to be opposed to third party-acquirers with a legitimate title. See D.G. van der Keessel, Theses selectae juris Hollandici et Zelandici, Leiden 180o, ad Inl. 2,48,29; W. Hinz, Die Entwicklung des gutgläubigen Fahrniserwerbs in der Epoche des usus modernus und des Naturrechts, Berlin 1991, p. 106. A second interpretation is possible, however. The pledging for the unpaid seller is then considered as that what happens in Rijnland only. The Holland rule is then that pledges are not traceable against third parties with a legitimate title. Only in Rijnland this is allowed. See Pos, Hypotheek op roerend goed (supra, n. 6), p. 184-185, and also Feenstra, Reclame en revindicatie (supra, n. 6), p. 137-138. The second interpretation is more consistent with Grotius' consilia. In 1632 he argued that alienation of a non-possessory pledge brought about the forfeiture of the pledgee's rights. See Hollandsche Consultatien (supra, n. 83), IV, p. 466-474 (22 February 1632). Moreover, this interpretation makes the passage fit with 2,5,14 and 3,15,4. Since in Grotius' theories the unpaid seller retained ownership by law, pledging was not necessary. It then seems that in Rijnland the seller did not retain ownership by law, but only following an express agreement with the buyer. 
('obligatie'), has priority over other competing creditors (s. 48). Yet, also, the pledgee is allowed to seize the assets delivered, which are encumbered by the obligatie, where he can find them, and also with a second or third buyer (s. 49). It is probable that these rules were a blend of a local tradition of third-party seizures with academic elements. The doctrinal contents can be deduced from the fact that the creditor was allowed only to have his debt paid from the asset, not to receive the asset itself (s. 50 ${ }^{105}$. Grotius over-interpreted the mentioned sections in considering the 'speciaal verband' as a contractual provision of sale, which the sections do not suggest. Instead, the pledge is vested in a clause of collateral, part of an acknowledgment of debt, issued after a sale.

Grotius did not explain to what extent the passages in 2,3,4-6 in the Inleidinghe, which deal with ownership and reivindicatio, are compatible with $2,5,14$ and 3,15,4. As was mentioned above, because he did not mention the contrary, it seems that Grotius intended that the unpaid seller, on the basis of his lien of reserved ownership, could recover the assets delivered from a bonafide buyer as well $(2,3,5)$. If $2,5,14$ and 3,15,4 were implicitly linked to $2,3,4-5$, then also 2,3,6, which contains the 'market rule', is to be considered as applicable ${ }^{106}$. In local laws in Holland, this rule related to the recovery of stolen assets only ${ }^{107}$. If stolen assets had been sold at a market place, then the buyer was protected against the reivindicatio of the owner; the owner had to pay the buyer his purchasing price in exchange for the assets. Grotius mentions the market rule with regard to reivindicatio in general, but he does not refer to the seller's lien. Yet Grotius's construct of the seller's lien as being based on ownership brings the unpaid seller within its scope, even though Grotius did not explicitly state this. When the market rule is interpreted as an exception to the rules mentioned in 2,5,14 and 3,15,4 in combination with 2,3,4-5, the market buyer loses the possession of the assets bought when being confronted with an unpaid seller. In fact, any third acquirer loses the assets that had been bought to an unpaid seller, but the market buyer is the only one who receives compensation for the purchasing price in return. For stolen assets, compensation of market buys makes sense. The owner can retrieve and claim the assets, which he lost - the price is then due because of the third party's good faith, which is

105 Costumen van Rijnland, S. van Leeuwen (ed.), Leiden 1667, p. 205-207 (s. 48-50). These articles are found in all previous editions of these costuymen, which date 1570 and 1620. See Feenstra, Vindikation (supra, n. 6), p. 362, footnote 35. Most authors have interpreted the Rijnland costuymen in the same way as Grotius did. See Pos, Hypotheek op roerend goed (supra, n. 6), p. 184.

106 Contra: Feenstra, Reclame en revindicatie (supra, n. 6), p. 141-142.

107 S.J. Fockema Andreae and L.J. van Apeldoorn (eds), Inleidinge tot de Hollandsche rechtsgeleerdheid ..., Arnhem 1939, II, p. 122. 
presumed in market sales. But for an unpaid seller, in combination with the new mixture with ownership, the rule takes on a meaning that is rather strange. The unpaid seller intended to forfeit his ownership rights, since he delivered the assets under sale. It therefore would have made more sense to value the interests of the holder higher than those of the seller.

In short, Grotius did envisage the unpaid seller's droit de suite, as logical corollary of his retained title, but seems not to have fully considered all consequences of this position. This is clear in his conception of tracing vis-à-vis third parties and in his understanding of the market rule. Also, the categorization of the seller's lien as being based on ownership could have meant that the unpaid seller as owner was to be treated as a 'separatist' super-priority creditor, who did not compete with other creditors. Could the unpaid seller lift his assets in their entirety from an insolvent's estate? Again, it is unclear to what extent Grotius construed such a super-priority to be a consequence of his categorizations.

Grotius largely neglected the earlier local and regional traditions of Holland, as he opted for a very Romanist approach. As explained above, this goes for ownership as label for the unpaid seller's rights. However, third-party party seizures out of sale were occasionally, and not in a consistent fashion, understood as involving ownership before Grotius' analysis as well. For example, the abovementioned 1557 Haarlem bylaws and the 1617 Amsterdam turbe on bankruptcy subsequent to a sale on express credit point to early conceptions of an ownership-based position of the unpaid seller. Also, in a legal advice of 1600 the unpaid seller is considered owner but at the same time he is referred to as competing with other creditors (over all of whom he is granted priority). However, in this advice the reclamation by the seller is not defined as reivindicatio against possessors ${ }^{108}$. Moreover, in the forensic practice of the Court of Holland third-party seizures were occasionally linked to ownership. Such seizures were lifted if the party under seizure or another party proved ownership of the seized assets (as was mentioned above, see under 3.5). In a case before the Court of Holland, probably dating from the 1580 s, the party under seizure of a third-party seizure alleged that the seizure was not possible because the seller had 'extended credit' ('fidem de pretio habitam asserit', referring to Inst. 2,1,41), which implicitly referred to the argument that ownership had passed ${ }^{109}$. Even so, notwithstanding these earlier examples, it was Grotius who consistently crafted the unpaid seller's claim as reivindicatio.

108 Hollandsche Consultatien (supra, n. 83), II, p. 258-259 (4 August 16oo).

109 Neostadius, Utriusque Curiae Decisiones (supra, n. 70), p. 137-138 (decisio 5, probably dating from the 1580 ). 
As set out, the market rule as devised by Grotius was very different from traditions in Holland. In the municipal law that prevailed in Holland in the sixteenth century, the market rule was not envisaged as applying to a seller, but only to an owner from whom had been stolen. Moreover, Grotius mentions the local rule that professional sellers such as pawnshop-keepers and dealers in second-hand clothing (oudekleerkopers) had a right to be compensated for stolen goods which they had bought without knowing, provided that they had been offered for inspection in public for at least three days $(2,3,6)$. This rule was indeed applied in some Holland cities such as Dordrecht ${ }^{110}$. But at the same time Grotius states that the compensation applied to any market buyer of good faith, and not only to pawnshop-keepers and cloth sellers. The buyer is obliged to return the assets, but has to receive the price he paid for the items bought $(2,3,6)$. This generalizing section in the Inleidinghe is at odds with these rules being presented as the common law of Holland. Dordrecht's approach was exceptional. In Amsterdam and Leiden an absolute right of tracing was granted for stolen assets, without imposed compensation, against market buyers or others ${ }^{111}$. The result is remarkable, also because the Grotian conceptions of the market rule had no support in Roman law. But it is not the only example of creative interpretation of local traditions by Grotius. A similar tactic of presenting a rule as Holland law, without much precedent in the local and regional laws ${ }^{112}$, is evident in Grotius presuming a clause 'à contant' in every contract of sale (see above paragraph 3.1). This was another academic strand of thought, going back to the commentators, but for which there was little backing in sources of the Holland local law.

Considering the seller's lien as ownership and allowing for the reservation of ownership at sale as conventional pledge, invited for the harmonizing of the rules relating to both arrangements. One inconsistency in the 1631 Inleidinghe was that tracing for the pledgee, in some regards, was less broad than for the owner. Indeed, the pledgee could not invoke his pledge against a third acquirer having a legitimate title, irrespective of whether the acquirer had paid for the assets or not. Without pledge, the seller could trace his assets with a third

110 J.A. Fruin, De oudste rechten der stad Dordrecht en van het baljuwschap van Zuid-Holland, Den Haag 1882, II, p. 5 (dating from 1406).

111 Breen, Rechtsbronnen der stad Amsterdam (supra, n. 17), p. 75 (1469), p. $15^{1}$ (1480), and p. 521 (c. 1500).

112 Admittedly, the 1617 Amsterdam turbe prohibiting tracing after subsequent bankruptcy in the case of express extension of credit points to a regime of conveyance of ownership when the price is fully paid. The clause 'on credit' only makes sense in such a context. Yet, there are younger Amsterdam turben or bylaws mentioning clauses 'à contant'. See, for example, footnote 118 . 
acquirer with a legitimate title, and also when the latter had paid for the assets. But if the subsequent sale had been made at a market, the holder was compensated for the price which he had paid. As a result, in some respects pledge procured fewer rights than the default contract of sale. Grotius seems to have struggled with this. In a 1638-1639 annotation, in preparation for a new edition of the Inleidinghe, Grotius restricted the forfeiture of the seller-pledgee's right to acquisitions by third parties on the basis of an onerous title ${ }^{113}$.

As a result, in any case, irrespectively of the brilliance of his legal analysis, Grotius did not achieve solutions regarding the recovery of delivered but unpaid movable items that were sound in all respects. There is little evidence supporting a derivation from practice, even though legal conclusions could have been inferred from it. The mentioned creative understandings of the Rijnland bylaws and of the market rule are cases in point.

Moreover, as was elaborated on in the first paragraphs, the source texts of Holland local law predating the 1580 s, even the early 1600 s, do virtually not mention an ownership-based seller's lien. But after the publication of Grotius' Inleidinghe this changed. One Amsterdam turbe of 31 July 1632 states that if a sale was 'à contant' the seller as owner could retrieve his merchandise not only with the buyer, but also with others. Moreover, it was stated that it was irrelevant whether the acquirer had paid a purchasing price. The two advocates and five proctors at the interview confirmed these rules as being 'in viridi observantia'. However, the turbe lacks the regular formula that the witnesses had seen this being practiced or imposed in judgments, which may point to the recent introduction of the rules ${ }^{114}$. Another source, a jurist's advice of 1641 mentions 'several' decisions by the Court of Holland and the High Court of the Dutch Republic which permit tracing by an unpaid seller against third parties ${ }^{115}$. Both sources depict the claim of the unpaid seller as a reivindicatio. In another Amsterdam turbe, of 1649, the interviewed proctors confirmed the unpaid seller's droit de suite against any holder, now adding that they had seen this being imposed by the aldermen-judges ${ }^{116}$.

A swift reception of Grotius' ideas can be explained when considering the earlier practice of third-party seizures. In procedural terms, the embracing of Grotius's views did not change a lot. But it seems that on the level of substantive law, the newly devised position of the unpaid seller was soon considered

\footnotetext{
113 H. De Groot, Inleiding tot de Hollandsche rechts-geleerdheid, F. Dovring, H.F.W.D Fischer and E.M. Meijers (eds), Leiden 1965, p. 190, footnote 5. On this remark, see Koops, Vormen van subsidiariteit (supra, n. 6), p. 133, footnote 13 .

114 Noordkerk, Handvesten (supra, n. 30), II, p. 502-503 (31 July 1632).

115 Hollandsche Consultatien (supra, n. 83), I, p. 461-462 (7 June 1641).

116 Noordkerk, Handvesten (supra, n. 30), II, p. 503 (30 June 1649).
} 
too powerful. For example, the Amsterdam aldermen felt obliged to intervene when several trials were conducted on the issue. In January 1658 , they stated that for any sale ' $a$ contant' the seller had to claim the price within six weeks, or start a proceeding in case of default, on the penalty of the expiry of the reivindicatio of the sold and delivered merchandise, also vis-à-vis third parties ${ }^{117}$. Similar bylaws were passed in other cities as well ${ }^{118}$.

Grotius' combination of the unpaid seller's lien and non-possessory pledges in sale contracts, meant that the adage 'meubles n'ont pas de suite', which in French legal doctrine had only concerned pledges ${ }^{119}$, was also more and more linked to the position of the unpaid seller. After 1631, Grotius' view of the seller's lien as concerning ownership trickled down into the forensic practice of cities, but also into doctrine. The legal authors Simon Groenewegen van der Made (ob. 1652) and foremost Simon van Leeuwen (ob. 1682) went farthest in mixing the two arrangements.

In 1644, Groenewegen published his annotations to Grotius' Inleidinghe, which were incorporated in the volume ${ }^{120}$. Extended notes were published in subsequent editions of the Inleidinghe, after Groenewegen's death, as from $1657^{121}$. As Grotius had done, Groenewegen distinguished strictly between pledge and the unpaid seller's lien, the latter of which he linked to ownership as well. Moreover, through his references Groenewegen implicitly reduced the scope of the market rule to stolen assets ${ }^{122}$, thus relying more on contemporary local approaches than on Grotius' views. Groenewegen also mentioned the exception to the forfeiture of the unpaid seller's lien in case the sale was 'on cred-

117 Noordkerk, Handvesten (supra, n. 30), II, p. 503 (31 January 1658).

118 Handvesten van Leyden, F. van Mieris (ed.), Leiden 1759, p. 251 (24 September 1659).

119 Also for Grotius. See his annotation in the Lund manuscript at 2,48,29: there he mentions section II,6o of the Sachsenspiegel as well as the maxim itself. There is no trace of Grotius' conflation of the maxim with the seller's lien. See Feenstra, Reclame en revindicatie (supra, n. 5), p. 137. Moreover, in a 1632 advice of Grotius it is confirmed that pledges of movables did not entail droit de suite and this is linked to the mentioned maxim. See De Groot, Inleiding, Dovring, Fischer and Meijers (eds) (supra, n. 113), p. 365 .

$120 \quad$ H. De Groot, Inleidinghe tot de Hollandsche rechts-geleertheyd, Dordrecht 1644.

121 H. De Groot, Inleydinge tot de Hollandsche regts-geleertheyt, Delft 1657.

122 Note 13 to Inleidinghe (1657 edition) 2,5,6 (ed. 1767, p. 125). This note refers to s. 23 ch. 3 of the 1495 Zeeland Keur, which is about the recovery of stolen goods. See Fruin, De keuren van Zeeland (supra, n. 49), p. 228 (ch. 3, s. 23). 
it', which was the buyer's swift subsequent insolvency ${ }^{123}$. In his 1648 De legibus abrogatis Groenewegen linked the maxim 'mobilia non habent sequelam' to Grotius' statement on the expiry of movable pledge in case of alienation ex causa onerosa $^{124}$. But Groenewegen did not refer in this regard to the lien of the unpaid seller.

Simon van Leeuwen built on Groenewegen's insights but went much further than Grotius and Groenewegen. First, he considered the market rule as applicable to both the owner of stolen assets and the unpaid seller (Censura forensis 1,14,19,20; Rooms-Hollands Regt 2,7,3). Secondly, during the course of his life, Van Leeuwen came to blend the unpaid seller's lien and pledge, even for the situation where pledge was not linked to a sale. In his Paratitula Iuris Novissimi (1652) (1,4,12,1-4, and 1,4,8,6), his 1662 Censura forensis, as well as in the RoomsHollands Regt of $1664(2,7,3$, and 4,17,3) Van Leeuwen still distinguished between both arrangements. Yet also, in the Censura forensis, he stated that the mobilia non habent sequelam rule is accepted both in Holland and France and that it makes the express pledge for the unpaid seller unfeasible in respect of movables $(4,8,3-6)$. It was only in his 1667 edition of the Rijnland costuymen that reservations were dropped entirely. He depicted the Rijnland customs, as concerning the unpaid seller's express pledge on delivered assets (s. 48-50), as an exception to a Dutch rule of 'les meubles n'ont pas de suite', which according to him concerned both the seller's lien and the seller's pledge. He presented this maxim as a principle of Roman-Dutch doctrine ${ }^{125}$.

As a result, Van Leeuwen was the first to explicitly conflate the seller's lien as silently retained ownership, the express pledge of the unpaid seller and nonpossessory pledges on movables. This was only done in 1667. In his Censura forensis of 1662, Van Leeuwen had not yet blended these arrangements, but had rather explored their mutual advantages and disadvantages. For example, he states that there is no need to stipulate a pledge if the sale is not expressly 'on credit', because in that case reservation of ownership before payment of the price is already the case $(4,8,3)$. In the wake of Grotius, Van Leeuwen insists that the sale 'à contant' is the default contract; credit of the price is not presumed, but must expressly be provided for.

\footnotetext{
123 Note 19 to Inleidinghe (1657 edition) 2,5,14. (ed. 1767, p. 143). Groenewegen referred to the Antwerp municipal law of 1582 .

124 S. Groenewegen van der Made, Tractatus de legibus abrogatis et inusitatis in Hollandia vicinisque regionibus, Leiden 1649, p. 500 (ad C. 4,10,14).

125 Only in his commented translation of Pieter Peck's De iure sistendi, dating from 1659, did he mention that it was a personal opinion. See Feenstra, Reclame en revindicatie (supra, n. 6), p. 141.
} 
However, these conceptions brought about new challenges. First, in promoting the mentioned maxim of 'mobilia non habent sequelam' into a general rule of Holland, Van Leeuwen was obliged to go back and forth between iura propria and the Roman-Dutch doctrine. He cites the 1658 Amsterdam bylaw, which limits reivindicatio for sales 'à contant', and infers from it the rule that 'les meubles n'ont pas de suite' applies to the unpaid seller as well ${ }^{126}$. Rather strikingly, in doing so Van Leeuwen arrives at aconclusion, opposite of Grotius, who had advocated broad powers of recovery for the unpaid seller. Second, the categorization of the seller's lien and the seller's pledge as being of the same kind, invited for creativeness regarding the nature of the claims involved. This had been on Van Leeuwen's mind before. In the title 8 of book 4 of the Censura $(4,8,3-6)$, Van Leeuwen considered the seller's lien as 'dominium', and the seller's pledge as 'pignus' or 'hypotheca'. But in a different fragment $(4,11,2)$, where Van Leeuwen analysed the express pledge of the seller in the context of the hierarchy of debts in case of the debtor's insolvency, he used - next to the notion of 'pignus' - the term 'quasi dominium'. He did not explain how this 'quasi dominium' is different from a regular ownership.

Both Groenewegen and Van Leeuwen combined rules that before had been linked to pledge only, with the seller's lien as it had been construed by Grotius. Moreover, as Grotius had done as well, they did so by way of overstretching the contents of sources of local law. Van Leeuwen cites the 1495 Zeeland bylaws' rule of reivindicatio of stolen goods, but according to him it reads that it allows the seller to claim the encumbered goods from a bona fide third party, if the latter had acquired ex causa onerosa ${ }^{127}$. A rule of the Antwerp bylaws of 1582 was interpreted such that it provided that the seller could claim the property back from third parties, if the buyer fraudulently went bankrupt. In the Antwerp section, however, there is no mention of recovery from third parties ${ }^{128}$.

126 Costumen van Rijnland (supra, n. 105), p. 205-206.

127 S. van Leeuwen, Censura forensis theoretico-practica, Leiden 1662, p. 554 (4,19,20); the bylaw is cited as 'Statut. Zeland. Anni 1495, cap 3, art 23'. For this section, see Fruin, De keuren van Zeeland (supra, n. 49) p. 228 (ch. 3, s. 23).

128 De Longé, Coutumes (supra, n. 65), II, p. 446 (ch. 58, s. 7). Van Leeuwen adheres to the mentioned interpretation, by way of projection of the reivindicatio on the article. See Van Leeuwen, Censura forensis (supra, n. 127), p. $554(4,19,20)$. Groenewegen is not very explicit in this regard. He quotes the contents of the article, and does not speak of a reivindicatio against third acquirers. See Note 19 to Inleidinghe (ed. 1657) 2,5,14 (ed. 1767, p. 143). 
For sixteenth- and seventeenth-century Holland, the creative aspects of legal reasoning and its impact on legal practice are most evident. In the later $1500 \mathrm{~s}$ the lien of the unpaid seller was still mainly considered a special debt for which third-party seizures could be laid. After 1631, unrestricted tracing by the unpaid seller was considered lawful because he was viewed as an owner, until from the later 1650 s onwards this became limited by municipal bylaws and in Van Leeuwen's writings. Over the course of the 1500 s non-possessory pledges of movables became general instead of special and a droit de suite, which exceptionally had been acknowledged before that time, became further restricted.

A comparison of these developments yields as conclusion that the shifts in the municipal law were regularly incited by new academic views. This is foremost the case with regard to the recasting of the unpaid seller's lien as a real rather than a personal right. But also the clause ' $a ̀$ contant' referred to doctrine, and the extension of the 'mobilia non habent sequelam'-principle in municipal law was caused by both princely law and legal writings. However, there was a commercial undercurrent to which the legal reforms responded. After around 1450 and throughout the sixteenth century notarial debt instruments and private acknowledgments of debt (obligaties) became widespread. The encumbrance of coins, the substitution of claims as well as third-party seizures were arrangements that reflected abstracted ideas, which were present both in trade and in legal environments. But even though commerce and mercantile practices and demands could trigger legal change, they were not always a simple cause. Sale was as important in fifteenth-century fair towns such as Dordrecht and textile hubs such as Leiden as it was in seventeenth-century Amsterdam. Major changes in the rules relating to the legal consequences of delivery at sales, which took place between $c$. 1400 and $c .1660$, cannot therefore be explained with references to economic conditions. The initial opposition of municipal administrators against court cases involving delivery notwithstanding postponed payment and clauses of 'ready money' did not last long because of the authority of academic doctrine.

It doesn't seem that merchants were advocating certain solutions. One possible cause of the extension of in-court seizure proceedings to all contracts and the restriction of extrajudicial remedies was that pledges became expressed more in writing and as provisions in written contracts. But these developments did not determine the contents of rules regarding the effects of these pledges. Legislators crafted law in answer to societal needs, but did not generally deduce concrete solutions from practices. Moreover, government intervention 
could serve political rather than economic interests. An example is the eradication of the extrajudicial thoonpand. Yet this did not hamper commerce per $s e$. What was needed in trade was not one or the other solution, but a system of rules that was consistent and transparent.

The academic influences incited opposition as well. It is remarkable that in the seventeenth century Amsterdam's leaders maintained sixteenth-century rules that had become outdated. Indeed, commerce did not favour or require one or the other rule, but it needed legal certainty nonetheless. As a result, loopholes that allowed for fraud had to be closed. In this regard, the Amsterdam regulations were not perfect. For example, sales on express credit did not entitle the unpaid seller for tracing if the buyer went bankrupt shortly after the sale. This may have been an incentive for fraudulent merchants to negotiate credit and swiftly re-sell the merchandise before going bust. But possibly further research will point out that this rule was engrained in the idea that exchange profits from the quick extinction of claims. This might then explain why at Amsterdam - and Holland - after $c .1660$ unpaid sellers and pledgees did not have many rights vis-à-vis third holders. But how can this then be reconciled with the prior tempore rule for general pledges? If trade was swift, why prioritize older debts over younger ones? Or was the rule purported so as to incentivize merchants to pledge and re-pledge only exceptionally, which might have been considered as supportive of commerce as well? ${ }^{129}$.

By 1650, the Roman-Dutch doctrine and municipal law of the cities in Holland had drifted apart, at least with regard to the effects of sale. But this changed to some extent. Van Leeuwen excluded tracing for unpaid sellers in respect of movable goods, which resembled municipal bylaws. Van Leeuwen's idea was not followed by Joannes Voet ${ }^{130}$. But later on, it seems that the right of the unpaid seller as reserved ownership was considered largely a theoretical option only, since most authors referred to the municipal rules ${ }^{131}$. In terms of pledges of movables, municipal and academic rules had remained largely similar throughout the later sixteenth and the seventeenth centuries, except for the effects on some pledges. Groenewegen and foremost Van Leeuwen were the authors that first assembled a more coherent framework concerning movable collateral taking the adage 'les meubles n'ont pas de suite' as baseline. It is

129 Answers will be provided in the doctoral dissertation by Maurits den Hollander (Tilburg University), which addresses the consistency and effects of Amsterdam's insolvency and securities law of the seventeenth century.

130 J. Voet, Commentarius ad Pandectas, Hagae Comitis 1726, I, p. 423 (ad D. 6,1, no 15).

131 C. van Bijnkershoek, Quaestionum juris privati libri quattuor, Leiden 1744, p. 495-505 (3,15); D.G. van der Keessel, Theses selectae juris Hollandici et Zelandici, Amsterdam 1840, p. 55 (ad Inleidinghe 2,5,14). 
ironic that these efforts were based on distorted interpretations of older texts of municipal law, even though contemporary forensic practices in cities in Holland were much closer to the ideas of these authors. Of course, not all differences between municipal law and academic doctrine became solved. A case in point are the municipal bylaws which, at least until the early eighteenth century, presumed conveyance of ownership in sales at delivery, except for when a provision ' $a$ contant' had been inserted into the contract ${ }^{132}$. By contrast, in the legal literature that came after Grotius it was commonly stated that delivery upon sale was presumed not to involve transfer of ownership before payment of the price. The legal authors considered that a separate clause ' $a$ contant' was therefore unnecessary since any sale was 'à contant' 133 .

Furthermore, despite the opposition of the Amsterdam legislator with regard to new rules, in municipal practice academic innovations were copied nonetheless. Turben at Amsterdam largely confirmed Grotius' analysis of the unpaid seller's lien and pledges, with terminology that was copied from doctrine. Admittedly, reception could be partial, or inconsistent, as the use of the clause 'for ready money' in the fifteenth century shows. The clause did not bring about real rights as was the case in the literature of the Commentators (Baldus). A full embracing of the academic doctrine on the theme would only take place in the second quarter of the seventeenth century, in the wake of Grotius' writings. But again, all this points to the thorough influence of legal thought and its predominance as catalyst of legal change.

132 For the municipal bylaws of Amsterdam, Leiden and Rotterdam, see Feenstra, Reclame en revindicatie (supra, n. 6), p. 129-133.

133 This was the position of Vinnius, Voet and Huber. See Carey Miller, Transfer of Ownership (supra, n. 6), p. 533; A. Vinnius, Commentarius in quatuor libros Institutionum ..., Leiden 1642, p. 295 (ad Inst. 2,1,41, no 3). 